\title{
Unions, technology, social-class, and earnings inequality in the US, 1984-2019
}

\author{
Saverio Minardi \\ University of Trento
}

\begin{abstract}
Earnings inequalities in the US have steadily grown in the last decades, and between-class inequalities have been a central component of this process. However, while research has highlighted the strengthening relationship between occupational social classes and earnings, less attention has been paid to what factors have altered the market returns of different social classes. The present article investigates the contribution of two of the most widely recognized drivers of wage inequalities - de-unionization and technological change - to the growth of between-class inequalities. Using direct measures for computerization and union density at the industry level, this article analyses their relationship to the earnings growth of employees in different social classes from 1984 to 2019. Descriptive results underline the diverging earnings growth of manual and non-manual workers. Furthermore, minor support is found for the claim that computerization at the industry level was associated with the earnings growth of salariat and nonmanual workers. In contrast, de-unionization is related to the diverging fortunes of manual and service classes in two ways. First, unionization is positively associated with the earnings of all social classes but more strongly with those of the lower classes. Second, manual workers were employed in much greater numbers in industries that experienced severe declines in union density and have thus been majorly affected by its decay. Finally, the growth in educational levels for non-manual classes emerges as a crucial determinant of their faster earnings growth. Overall, results support recent sociological literature suggesting that institutional factors, rather than technological change, are primarily responsible for rising inequalities in the US.
\end{abstract}

Key words: Social class; earnings; inequalities; technological change; de-unionization 


\section{Introduction}

Starting from the 1980s, the distribution of personal earnings in the US has become substantially more unequal, breaking a general pattern of decreasing inequalities that dates back to the beginning of the twentieth century (Levy \& Murnane, 1992; McCall \& Percheski, 2010; Piketty \& Saez, 2003). A large body of sociological research has investigated whether this take-off in earnings inequality has played out in a way that strengthens or weakens inequalities between occupations and aggregate social classes, and a long debate emerged investigating whether earnings inequalities were mainly driven by changes in class income differences, by changes between occupations within the same class, or by changes within occupations (Kim \& Sakamoto, 2008; Mouw \& Kalleberg, 2010; Weeden et al., 2007; Zhou \& Wodtke, 2019).

Among these dimensions, social class inequalities are of paramount interest to sociological research since they combine homogeneous socio-economic groups, filled with individuals who share similar life conditions, expectations, skills, career trajectories, and earnings (Breen, 2005). As a result, an increase in economic inequality between classes would almost surely result in a more separate and hierarchical social order, possibly exacerbating the social and political implications of inequality (Edlund \& Lindh, 2015; Evans, 2000; Lipset, 1960; Wilkinson \& Pickett, 2011).

While existing studies on the decomposition of overall levels of inequalities have underlined the progressive consolidation of the relationship between social classes and earnings (Goedemé et al., 2020; Morgan \& Tang, 2007; Weeden et al., 2007; Zhou \& Wodtke, 2019), little research has been carried on the reasons and macro determinants of this process. On the other hand, several studies have explored the drivers of overall wage dispersion and the functional distribution of income (Elsby et al., 2013; Kristal, 2013; Kristal \& Cohen, 2017; Lin \& Tomaskovic-Devey, 2013).

Results from this body of research have generally pointed towards two main factors behind rising inequalities. A first strand of primarily economic literature has suggested that computerisation and technological change have increased the productivity and wages of more skilled workers relative to less skilled ones. On the other hand, social science research has repeatedly shown that the demise of wage-setting institutions and workers' power has inhibited wage growth for lower incomes and increased earnings dispersion (Card et al., 2017; Kristal, 2013; Kristal \& Cohen, 2017; Lin \& Tomaskovic-Devey, 2013; Western \& Rosenfeld, 2011; Blau \& Kahn, 2009). Finally, a growing body of research has highlighted the combined effect of these two factors, suggesting a moderating and mediating effect of de-unionization in the relationship between technological change and labour market inequalities (Acemoglu, 2001; Kristal, 2015, 2019).

The present article attempts to combine these two strands of research by investigating how these crucial factors - i.e., technological change and de-unionisation - have diversely influenced the earnings growth of employees in different social classes, therefore exacerbating class inequalities in the US in the period from 1984 to 2019. However, given the extensive research on the functional distribution of income -i.e., inequalities between capital owners and workers - the present article focuses exclusively on social class inequalities 
between employees, as they make up the vast majority of the working population. Furthermore, the mechanisms connecting technological change and institutional factors to inequalities between groups of workers may be substantially different from those hastening disparities between workers and capital owners.

Thus, based on industry-level data, the article investigates whether changes in technological endowments, institutional settings and labour force composition diversely impacted the earnings growth of different aggregate social classes defined using the EGP classification (Erikson \& Goldthorpe, 1992).

Results highlight the diverging fortunes of services and manual workers. The formers have experienced significant wage growth in the analysed period, while the latter's earnings have stagnated or declined. Results suggest that technological change at the industry level had little relation with the earnings trajectories of all social classes. In contrast, the industrial union density positively affected all social classes' earnings, but more so those of manual classes. Moreover, the fall in union density appears to be the most relevant factor explaining diverse earning growth between manual and non-manual workers due to the different exposure to deunionisation between these two groups. In other words, a more significant part of skilled and non-skilled manual workers compared to salariat and routine non-manual workers were employed in industries that experienced substantial declines in union density in the period examined. Little evidence emerges of a mediating or moderating effect of unionization in the relationship between ICT investments and the earnings of each social class. Finally, results suggest that changes in each class's demographic and educational composition also played an important role.

The remainder of the article is structured as follows. The first section reviews the main literature connecting employees' class position to market returns and earnings. The second section highlights the importance of macro institutional factors in shaping the relationship between social class and earnings; it focuses explicitly on technological change and unionisation and how they influence workers employed through a labour contract or service relationship. Section three introduces data and methods, while section four presents the results from a panel analysis, and section five discusses the findings.

\section{Social class and earnings}

Social class, and its relation to unequal economic returns, has been one of the most relevant and useful, as well as debated and contested, concepts of social analysis (Wright, 2005). Indeed, many different theoretical definitions and operationalisation of social class exist, each rooted in different traditions. Albeit this section does not claim the superiority of one approach over another, it mainly builds on the so-called Weberian tradition primarily associated with the work of John Goldthorpe and colleagues and the development of the EGP class schema (Erikson et al., 1979; Erikson and Goldthorpe, 1992; Goldthorpe, 2000; Breen, 2005). Nevertheless, most of the arguments connecting social class positions to earnings inequalities are not exclusive to any theoretical tradition of social class but are easily extendable to other approaches ${ }^{1}$.

\footnotetext{
${ }^{1}$ Indeed, the EGP schema has often been characterized as neo-Weberian, but it appears more accurate to consider it an amalgam of mainly, but not exclusively, Weberian and Marxian principles. Indeed, Erikson and Goldthorpe (1992) stressed that "the opposition
} 
In Erikson and Goldthorpe (1992), social classes are understood as bundles of individuals who share common economic life chances due to their position within labour markets and work organisations. The primary underlying assumption is that social class - typically proxied by the occupation an individual belongs to - is a good indicator of access to economic resources, first of all, earnings (Goldthorpe \& McKnight, 2006; Morgan \& Tang, 2007). Therefore, the objective of defining a meaningful classification of social classes lies in identifying what puts individuals in a common position.

In Goldthorpe's schema, classes depict the distinctions between proprietors vs non-proprietors and, among employees, between those whose position is regulated by a "labour contract" and those regulated by a "service relationship." At the basis of the distinction between these two lies the contractual hazard employers face in solving two main problems: work monitoring and asset specificity. The former occurs where the employer cannot strictly control a worker's productivity on the job - and thus explicitly relates to the degree of job autonomy and discretion over the tasks undertaken. Human asset specificity, instead, refers to the content of a job in terms of specific skills, qualifications, or information. These are job-related characteristics, and variations in these attributes explain the different employment relationships between workers and classes.

To boost employees' efficiency in difficult-to-monitor jobs and reduce the risk of employees' turnover in asset-specific jobs, the employer must elicit commitment to the company from the employees involved. The service relation is the tool for doing this: a compensation arrangement that binds employees to the company by providing job protection and good internal career opportunities, not least in terms of earnings growth. Hence the disparities in earnings between classes. Higher earnings - the so-called "efficiency wage" (Akerlof, 1984) - are very likely to be a crucial part of employers' benefits to the upper classes ${ }^{2}$. On the other hand, occupations with low human asset specificity and low monitoring problems constitute the working class, controlled via labour contract and workplace discipline.

Besides the working class and the salariat, other groups are characterised by employment relationships that take on a mixed form. These are routine non-manual workers, lower grade technicians, and skilled manual workers (Erikson and Goldthorpe 1992, p. 43). However, these mixed forms occur for different reasons in each case. For example, routine non-manual jobs like clerks, secretaries, and other routine administrative employees usually do not require asset-specificity but pose specific monitoring challenges, whereas, in the case of professional manual workers and technicians, the opposite holds. The consequent incentives and rewards position these occupations in a theoretical "middle" between the working and service classes.

\footnotetext{
between Marxist and Weberian conceptions of class is in many respects exaggerated", they do accept that "The principles of differentiation that we adopt have been mainly derived from classic sources, in particular, from Marx and Max Weber." (p. 37)

${ }^{2}$ It is important to notice that the rationale highlighting a causal link between social class and earnings is similar to that suggested by Marxist approaches to social class. In the same vein as Goldthorpe, Wright (1997) recognizes that the essence of the work performed by the upper classes is such that employers are incentivized to devise methods to cultivate the loyalty and dedication of upper class workers, and salaries are an important means of achieving that goal. In addition to what is beneficial from the standpoint of the employer, Wright emphasizes the importance of the bargaining power of different classes. Because of their strategic role within the company, managers and professionals can advance claims and bargaining for a portion of the profit in the form of higher earnings. Managers can thus claim a "loyalty rent," while specialists can claim a "skill rent." These claims imply a causal relationship between social status and earnings.
} 
In addition to monitoring difficulties and asset specificity, social classes can be tied to different socioeconomic returns through skill requirements and related productivity levels (Le Grand \& Tåhlin, 2013; Tåhlin, 2007). Indeed, even if productivity is not usually considered in the main theoretical definitions of social class, employees in the service class can obtain comparatively significant gains from the productive value of their duties, highly worthen in the employer's eyes. Thus, according to this perspective, jobs in upper-class occupations have higher incomes because their experience, training, and expertise make them more profitable. This viewpoint suggests that class is a reasonable indicator for income disparity since it captures workers' talents and skills. ${ }^{3}$

\section{Technology, unions, and changing economic returns to social class}

As seen, social class theory connects employees' class position to earnings through mechanisms mainly related to workplace relations, such as the need to monitor or reward workers. However, other institutional and contextual factors play a crucial role in explaining wage levels and differentials.

Social class implies that individuals' position in the labour market results in different social and economic advantages and disadvantages. However, the strength of this link is influenced by several contextual factors, including labour market regulation, bargaining power, and technological advancements. Since many of these contextual aspects have radically changed over the last decades, one would also expect changes in the relationship between class and income.

Therefore, it is not surprising that differences in earning returns between classes in the US have taken off since the US economy experienced significant transformations in labour market composition, technological endowments, and unions' power. Each of these factors may indeed substantially alter the market position of different groups.

This understanding reflects Breen's (1997) suggestion that an occupation, or group of occupations, may benefit from certain aspects of the service relationship not solely because it maximises productivity but also because the workers' bargaining power enables them to capture these aspects in the form of rent. It is plausible that transformations in the terms and conditions of employment governing many jobs over the last twenty years are attributable to the worsening of workers' bargaining position vis-a-vis employers as well as to changes in the skill requirements of these jobs and the new job monitoring opportunities associated to recent technological change. Based on these claims, the returns to a class position do not follow so quickly from a simple consideration of productivity and workplace relations. Other historical, institutional, and technical factors must be considered in justifying any specific change in class structures and social stratification.

\footnotetext{
${ }^{3}$ In addition to ability and talents, other aspects associated with the class may explain class disparities. A correlation between class and earnings is likely to be observed because social status is linked with a particular individual or household attributes associated with earnings. Earnings would then be linked to social status through various alternative routes such as gender or race (Morgan \& McKerrow, 2004). However, as Rose and Harrison (2014) argue, these alternative dimensions can also be seen as components of social class disparity, giving support to class theory.
} 
According to a large body of research on the determinants of earnings dispersion and the fall in the labour share, technological change and the demise of unions' power and wage-setting institution can be considered the most critical factors in explaining rising inequalities in the US. As argued below, many of the arguments connecting these factors to the overall distribution of earnings are also crucial in defining economic returns to different social classes.

\section{Technological change}

The factor most often deemed responsible for the change in market returns for different occupational groups has been the process of technological change. As it took place in the last decades, technological development can be considered connected to the market position of different social classes in at least three ways. First, through its complementarity to skill levels, second through its relation to the tasks content of work, and third through its connection to workers' autonomy and power.

Following the seminal contributions by Krueger (1993), Berman et al. (1994) and Goldin \& Katz (1998), the theory of Skilled-Biased Technological Change (SBTC) maintained the primacy of technological change in determining a generalised skill upgrading of the workforce. Under this perspective, technology was considered the main explanatory factor behind rising college wage premium, suggesting that information and communication technologies were mainly complementary to highly skilled workers, thus raising returns to skills.

After observing the polarising trend in the US earnings and occupational distribution, the theory of SBTC was revised and refined by the theory of Routine-Biased Technological Change (RBTC) (Autor et al., 2003). RBTC distinguishes occupations based on the content of their tasks. Technological change is expected to substitute workers performing routine tasks while complementing the execution of abstract cognitive and interpersonal ones, thus increasing demand, productivity, and eventually earnings for occupations characterised by more cognitive and non-routine duties.

Both SBTC and RBTC are closely related to the concept of social class. Indeed, the definition of a social class depends on the skill level, the type of work, and the tasks that employees undertake, thus leading to different employment relationships - based on labour contract or service relationship. As a result, both SBTC and RBTC would suggest a positive association between the earnings of occupational categories which perform more skilled, more cognitive and thus less monitorable tasks such as managers, professionals, and non-manual workers in general.

A second channel through which technological change may have contributed to diverse earnings growth between social classes is by altering the monitoring problem faced by employers, increasing managements' and employers' ability to monitor and control low-skilled workers, thus strengthening the dynamics underlying the labour contract (Guy \& Skott, 2015; Skott \& Guy, 2007).

Starting with the early work of Braverman (1974), socio-economic research has suggested that technologies lead to higher monitoring, lower skill requirements, and more precise tasks specification, and 
especially so for lower-skilled workers whose tasks do not require expert knowledge and creative thinking (Hunter \& Lafkas, 2003; Menon et al., 2019). The growth in usage of ICT technologies since the 1970s has had the potential to reduce the autonomy and control over the work process of lower-level employees, therefore tempering their wage growth.

On the other hand, managerial activity is aimed at the efficient production of output and involves high levels of decision-making after collecting and analysing information. ICT technologies have drastically increased the amount of information and options available to higher-level employees. This large amount of information and possible path of action strongly aggravate the monitoring problem for higher classes (Guy \& Skott, 2013). As suggested by Kristal (2020), computerisation may have strengthened the market position of some occupations due to their different access and control of information on the production processes. On the one hand, these include occupations involved with the management, circulation, and reorganisation of information and data (such as computer programmers, information systems specialists). On the other, those who receive this information flow and translate, interpret, and use them to support decision-making strategies, such as managers and professionals.

Eventually, existing theories of technological change would suggest a positive relationship between technological change and the earnings of higher classes - due to their higher skill set, the type of tasks performed, and power relations related to the control and use of information flows - an a negative relationship to those of the working classes. More ambiguous is the relation to the earnings trajectories of those classes characterised by a mixed relationship. On the one hand, RBTC indicated that these middle-classes are the most substitutable due to their higher content of routine tasks (Autor et al., 2003). Similarly, Breen (1997) suggested that the market positions of these classes were particularly at risk due to new detailed methods of monitoring and their vulnerability to technological change. At the same time, these are occupations characterised by considerably higher skill requirements, interpersonal tasks, and use of information (especially those constituting the non-manual workers) compared to the working classes and may thus benefit from productivity gains spurred by technological change.

\section{Unionisation}

Literature on routine and skilled biased technological change has often disregarded the crucial role of labour market institutions. Nevertheless, institutions are critical determinants of earnings inequalities, and research has consistently indicated that more coordinated and inclusive institutional arrangements are generally associated with lower levels of inequalities, while their impact on other socially relevant outcomes - such as unemployment levels - is less straightforward (Esping-Andersen, Regini 2000; Checchi et al. 2008; Barbieri, 2009).

Among the most relevant institutions to be considered, when dealing with wages and earnings distribution in US labour markets, trade unions deserve a central position due to their impact on income inequality via the increase in wage levels and the related drop in wage dispersion (VanHeuvelen, 2018; Western \& Rosenfeld, 2011; Acemoglu et al. 2001). 
Indeed, unions are collective actors who increase labour's power resources and improve labour's bargaining position against capital owners and employers, positively affecting employees' economic returns (Jacobs \& Dirlam, 2016; Kristal, 2013). Thus, the most obvious channel through which trade unions can reduce inequalities is by directly bargaining higher earnings for unionised workers (Brady et al., 2013; Card et al., 2017; Freeman, 1984; Maxwell, 2008), and particularly so for less educated and manual ones (Freeman, 1980; Kristal, 2013; Maxwell, 2008; Mishel et al., 2012; Western \& Rosenfeld, 2011). For this reason, the decline in unionization can be expected to play a crucial role in the growth of social-class inequalities.

However, bargaining for union members is only one of the potential paths through which unions affect the overall distribution of wages. As literature has shown, trade unions also positively affect the earnings of nonunionised workers and increase the overall labour share of total income by combining collective bargaining and support for minimum wage (Grimshaw et al. 2014; Checchi, Lucifora 2002), through spill-over effects, and through threats to non-unionised firms (Denice \& Rosenfeld, 2018; Freeman, 2005; Leicht, 1989).

Furthermore, recent literature has suggested that trade unions may exert a positive effect on the wages of non-unionised workers by promoting a vast set of egalitarian norms and principles prescribing fair distribution, usually reassumed under the label of a "moral economy" (VanHeuvelen, 2018; Western \& Rosenfeld, 2011). Finally, the positive effect of unions may spread to other non-unionised workers through social comparison, given that higher wages bargained by unions can establish higher expectations for the whole industry in which unions operate (Alderson \& Katz-Gerro, 2016; Rosenfeld, 2006).

Despite unions' potential to raise earnings for all workers, their positive effect is particularly relevant for lower-skilled and manual employees (Freeman, 1980; Kristal, 2013; Maxwell, 2008; Mishel et al., 2012; Western $\&$ Rosenfeld, 2011). Indeed, lower classes cannot bargain wages based on their favourable workplace position since they rely on different contract relationships and have poor individual bargaining power (Rosenfeld, 2006). As a result, unionisation and labour regulating institutions have traditionally been the primary way workers in classes regulated by a labour contract have gained part of the privileges typical of service classes. It follows that a decline in the labour movement's bargaining power primarily affects this group of workers.

As suggested by Breen (1997), part of the benefits that lower and intermediate classes enjoy have been acquired through labour mobilisation when labour-power was much more significant than now. Under this perspective, the stagnation in earnings observed for middle and lower classes since the '90s and 80 s can be understood as the erosion in rent acquired in previous periods.

A second reason the decline in unionisation may have been more relevant for the earnings of lower and manual classes is their different exposure to the phenomena. Workers in lower classes and manual workers are more present in industries that experienced strong de-unionisation processes. As a result of this uneven distribution of social classes between more or less unionized industries, even a similar functional relationship between unionization and earnings between social classes may result in more significant earning losses for lower classes. 
As a result, the decline in unionisation rates observed in the US in the last decades emerges as a crucial factor behind the stagnation in working-class earnings and consequent inequalities between social classes (DiNardo et al., 1996; Mishel et al., 2012; Parolin, 2021; Rosenfeld, 2006; Western \& Rosenfeld, 2011).

Finally, it is crucial to recognize that the two "forces" - de-unionisation and technological change - are not simply additive factors but are likely to be interrelated. On this specific point, recent studies have stressed that technological change and unionization are associated and that the process of (de)unionization may act as a mediator of the direct link between technology and economic inequality. Moreover, strong unions can moderate the impact of technological change either by containing its impact on the wage growth of higher classes or by limiting the increase in the deskilling and disempowerment of less-skilled workers (Acemoglu, 2001; Kristal, 2015, 2019).

\section{Data and variables}

The connection between unionisation, technological innovation and earnings change between different social classes is tested using longitudinal data on US private non-agricultural industries from 1984 to 2019. The unit of analysis is defined by the combination of 40 industries and four social classes observed for 36 years, yielding a total of 5760 industry-class-year observations clustered in 160 industry-class groups.

Information on individual earnings and socio-demographic characteristics are taken from the CPSMORG harmonised by IPUMS (Flood et al., 2020). The sample is restricted to full-time employees (at least 30 hours per week $\left.{ }^{4}\right) 18$ to 69 years old.

Social classes are defined using the EGP class schema adapted by Morgan (2017) to the 2010 census occupational classification ${ }^{5}$. Throughout the years analysed, the CPS underwent some modifications to the occupational classification, the most severe of which took place in $2002^{6}$. Therefore, in order to obtain a consistent classification of social classes, all occupational codes are converted into a common 2010 definition using crosswalks provided by the US Census Bureau (Scopp, 2003) (see appendix for details on the occupational crosswalk) and then into EGP categories based on Morgan (2017).

Social classes are defined using the seven-class version of the EGP suggested by Goldthorpe (1992), which results in four categories after excluding the self-employed (class IV) and agricultural workers (class

\footnotetext{
${ }^{4}$ After 1994 the CPS has included the option "hours vary" among the possible responses to the question "hours usually worked per-week." In this article, individuals who reported "hours vary" after 1994 are treated as non-full-time workers and thus excluded from the sample. The inclusion of these respondents creates a significant break in time-series after 1994 and some authors (Schmitt, 2003) suggest that estimates appear more reliable by excluding them. However, analyses including these workers in the sample are almost identical.

${ }^{5}$ The EGP schema has become, in the last decades, the most prominent given its deployment in a number of different research contexts, among which social mobility, (e.g. Erikson \& Goldthorpe, 1992; Hout, 1989), voting behaviour (e.g. Heath et al., 1985; Manza \& Brooks, 1999), health, earnings and career trajectories. The EGP schema also appears robust from a theoretical standpoint (see Goldthorpe, 2000), based on a wide range of literature from both economics and sociology (see Erikson \& Goldthorpe, 2002).

${ }^{6}$ Other than the 2002-2003 change, occupational codes in the CPS were revised in 1992 and 2011.
} 
VIIb) ${ }^{7}$. The resulting categories are the salariat (classes I-II), routine non-manual (classes IIIab $^{8}$ ), skilled manual (classes V-VI) and unskilled manual (class VII). ${ }^{9}$

Industries are defined based on an approximation of the two-digit NAICS classification that matches the Bureau of Economic Analysis data on industry investments. As occupations, industrial classification underwent some changes in the period under analysis. The present analysis starts with the harmonisation to the 1990 census industry code performed by IPUMS (IPUMS USA, 2018). Then, it converts to the 2012 NAICS classification using the crosswalk from the US Census Bureau (2013) to match data on technological investments ${ }^{10}$ (see appendix for more details on industry harmonisation and the complete list of industries).

The dependent variable of interest is the mean of ln weekly earning for each social class. Weekly earnings are adjusted for inflation using the CPI and set to 2000 USD. Individuals reporting less than 50 dollars per week are excluded, and top coded earnings are imputed, assuming a log-normal distribution (Schmitt, 2003). Different procedures to deal with the top coding lead to the same conclusion. In particular, the primary model is tested using the median of industry-class earnings (see table A2 model 2 and table A4 model 14 in the appendix).

Using the MORG-CPS, a number of information on socio-demographic characteristics on each unit is computed: the share of tertiary educated, the share of females' workers, the share of white non-Hispanic workers, and average age. All industry-class-year aggregate statistics are computed using sampling weights.

The two main industry-level variables are union density and computer investments. As usually in the literature, union density is measured by the ratio of union members in each industry by the number of total wage and salary workers aged 16 and over. It is thought to capture overall sectoral unions' power rather than the representation of any specific group, thus reflecting the idea that unions exert an influence on economic conditions beyond unionised workers. As recent sociological literature on technological change and industry level inequalities, the industry's reliance on computer technologies is measured as investments in computers and software as a share of total non-residential investments using data on investments in fixed assets from the Bureau of Economic Analysis (BEA) (Kristal, 2013; Kristal \& Cohen, 2015, 2017; Lin \& Tomaskovic-Devey, 2013). Computers include investments in mainframe computers, personal computers, direct access storage

\footnotetext{
${ }^{7}$ After the exclusion of the agricultural sector few agricultural workers - class IVc and VIIb - are still in the sample. These are combined respectively to class I-II and VIIa.

${ }^{8}$ In some cases, class IIIb is merged with class VII rather than a single class III (see for example Breen, 2005; Tåhlin, 2007). However, as shown by Evans (1992) class IIIb is more similar to IIIa than VII in a number of aspects of the employment relations. Furthermore, the present study is mainly interested in earnings change over time and Figure 1 highlights that class IIIb has experienced earnings trends quite similar to class IIIa.

${ }^{9}$ The analysis is restricted to four aggregate social classes instead of a more fine-graded definition due to limited yearly sample size, which would otherwise result in some empty industry-class-year cells, and to limit breaks in time series due to the changing occupational classifications.

${ }^{10}$ Some industries are aggregated to a two-digit NAICS due to low numerosity or ambiguity in the cross-walk. The intersection of industry class and year does not result in empty combinations, however, in some cases it results in low cell numerosity which produce quite noisy time series. To deal with this issue a number of different strategies are adopted. First, models are tested excluding units made up by less than 50 and less than 100 observations (see table A2 models 3 and 4, and table. A4 model 15 and 16 in the appendix). Second, models are tested weighting each unit of analysis by its average cell numerosity (see table A2 model 5 and table A4 model 17 in the appendix) so that small (and noisier) units contribute less to the estimation. All specification lead to the same conclusions.
} 
devices, computer terminals, computer storage devices, integrated systems, and software. Finally, the log of real industry value added from the BEA is included as a control variable to account for different economic growth rates between industries.

\section{Methods}

The method of analysis aims to investigate the relationship between indicators of computerisation and union density at the industry levels and industry variations in the earnings of each social class. The main specification is a dynamic two-way fixed effect model estimated separately for each class, including industry-class fixed effects, class-year fixed effects and a lagged dependent variable among the predictors as reported in Equation [1]. Fixed effects estimators exploit within industry-class variation and therefore control for time-constant heterogeneity between units. In this way, it focuses on the within industry-class variation over time, and coefficients represent the average cross-industry longitudinal effect for each social class. The model further includes year fixed effects to account for specific time shocks and trends which affected all industries. Finally, a lag of mean ln earnings for each social class is included among the predictors to control for potential serial correlation and for the fact that earnings are path-dependent, i.e., current earnings for each class are bargained based on the levels of the previous year earnings ${ }^{11}$ :

$$
Y_{\text {cit }}=\alpha_{1} Y_{\text {cit-1 }}+\beta_{0} I C T_{i t}+\beta_{1} \text { Union }_{i t}+\beta_{n} X_{c i t}+a_{1 c i}+a_{2 c t}+\varepsilon_{c i t}
$$

$Y_{c i t}$ represent the earnings of social class $c$ in industry $i$ at time $t, Y_{c i t-1}$ is a one-year lag of the dependent variable, $I C T_{i t}$ and Union $_{i t}$ represent respectively the intensity of investments in computer technology and unionisation at the industry level; $X_{c i t}$ is a vector of industry-class and industry-specific characteristics. Industry-class covariates include the share of tertiary-educated workers, the share of female workers, the share of white non-Hispanic workers, and the average age. The industry level control is the log of real value added to account for different economic growth rates across industries and industry-specific economic downturns. $a_{1 c i}$ are industry-class specific intercept which accounts for unobserved time-constant heterogeneity at the industry-class level, $a_{2 c t}$ are yearly-class intercepts which account for year-class specific economy-wide shocks.

As mentioned above, to investigate the diverse effect of each covariate on the earnings of different social classes, the model is estimated separately for each social class, resulting in four different datasets made up of 40 industries observed for 36-time points. It must be noted that the estimation of four separate models is

${ }^{11}$ One of the potential disadvantages of this strategy is that the inclusion of a fixed effect term $\mathrm{a}_{1 \mathrm{ci}}$ and a lag value of $\mathrm{Y}$ $\alpha_{1} \mathrm{Y}_{\text {cit-1 }}$ could result in the so-called Nickell bias Using the standard within-group estimator for dynamic models with fixed individual effects generates estimates which are inconsistent as the number of "individuals" tends to infinity if the number of time periods is kept fixed (Nickell, 1981). However, it usually vanishes with a long time-dimension as in this case (Judson and Owen 1999). 
equivalent to estimating one fully interacted model, where each covariate is interacted with social class, and coefficients are interpretable as differences from the reference category. In order to facilitate interpretations, results are presented as separate models and the equivalent interacted model is presented in tables A2 to A5 (appendix) to test statistical difference between the reference class (the salariat) and other classes.

One potential problem in analysing cross-section time-series data is that time series are likely to be nonstationary, increasing the risk of spurious relations due to the variables trending together over time. A common way to deal with non-stationarity is to estimate models in first difference. While the first difference is a convenient technical solution, it estimates only short-term effects because it removes any long-term information. However, the presence of non-stationarity does not rule out any long-term relationship, which is the main interest of the current analysis.

A second option to estimate long and short-term relationships simultaneously are single equations error correction models (ECM) as Equation 2. ECMs allow for the simultaneous estimation of short-term and longterm effects while dealing with variables non-stationarity (De Boef \& Keele, 2008). An ECM as in Equation 2 is thus estimated:

$$
\begin{aligned}
& \quad \Delta Y_{c i t}=\alpha_{1} Y_{c i t-1}+\beta_{0} \Delta I C T_{i t}+\beta_{1} I C T_{i t-1}+\beta_{2} \Delta \text { Union }_{i t}+\beta_{3} \text { Union }_{i t-1}+\beta_{n 0} \Delta X_{c i t}+\beta_{n} X_{c i t-1}+ \\
& a_{1 c i}+a_{2 c t}+\varepsilon_{c i t}[2]
\end{aligned}
$$

Where $\Delta \mathrm{Y}_{\text {cit }}$ is the first difference of the mean of ln earnings for each social class, and all other covariates enter the Equation both in differences and in one period lag in levels. The ECM as reported in Equation 2 is a reparameterization of a panel autoregressive distributed lag model similar to the one reported in Equation 1, and coefficient in level variables are thus comparable to those estimated from Equation 1.

Finally, to investigate the potential moderating effect between the two main explanatory variables, both models are estimated including an interaction term between the indicators of ICT investments and unionisation.

Estimates of models one and two are not readily interpretable in regard to each factor contribution to overall national earnings trends over the period analysed for each class for two reasons. First, the models are dynamic, meaning that the effect of each covariate on $\mathrm{Y}_{\text {cit }}$ continues to affect later periods through its lagged values. Second, models one and two are informative only of the functional relationship between the covariates of interests and earnings of each social class and do not account for the actual exposure of workers in each class to changes in analysed factors. However, as mentioned above and as shown in figures A2 and A3 (appendix), workers in different social classes were diversely distributed across industries more or less affected by technological change and de-unionisation. As a result, despite similar functional relationships, each industry level factor may have contributed differently to each social class's overall national earnings trajectory.

To better understand the actual contribution of each factor to the earnings growth of different classes in the period analysed, a series of dynamic counterfactual estimates are derived from models in Equation 1 (see appendix for technical details). The observed earnings trends for each social class are compared to what they might have been if unionisation, investments in technology, and educational levels were fixed at the 1984 
levels. Forecasts for each class industry combination are then combined to the national levels by computing yearly class averages of the forecasts weighted by the class industry employment size to reflect overall national earnings trends for each class. The difference between the observed trend and the counterfactual trend can therefore be interpreted as the net impact of each factor that was realised in the observed period.

\section{Results}

Before moving to the econometric results, this section presents some descriptive analysis on the evolution of earnings of different social classes over the period under analysis. Figure 1 shows the evolution of weekly earnings from 1983 to 2019 for five categories of the EGP schema. The left panel shows the average real weekly earnings in 2000 USD for each social class. Besides giving a first grasp of the increase in earnings for the higher classes, the left panel of figure 1 highlights the different market positions of the five social classes in terms of earnings. The Salariat class has a clear advantage that has increased throughout the period analysed, followed by skilled manual workers (class V-VI) and higher-level routine non-manual workers (class IIIa), the two classes characterised by a mixed relationship. Albeit skilled manual workers received higher earnings than routine non-manual, average earnings of the two groups have converged in the observed period. Finally, class VII and IIIb are the less paid, with similar average earnings but very different growth rates in the period analysed.

Figure 1 Mean weekly earnings by EGP classes (left panel) and cumulative change in mean of In weekly earnings (right panel)

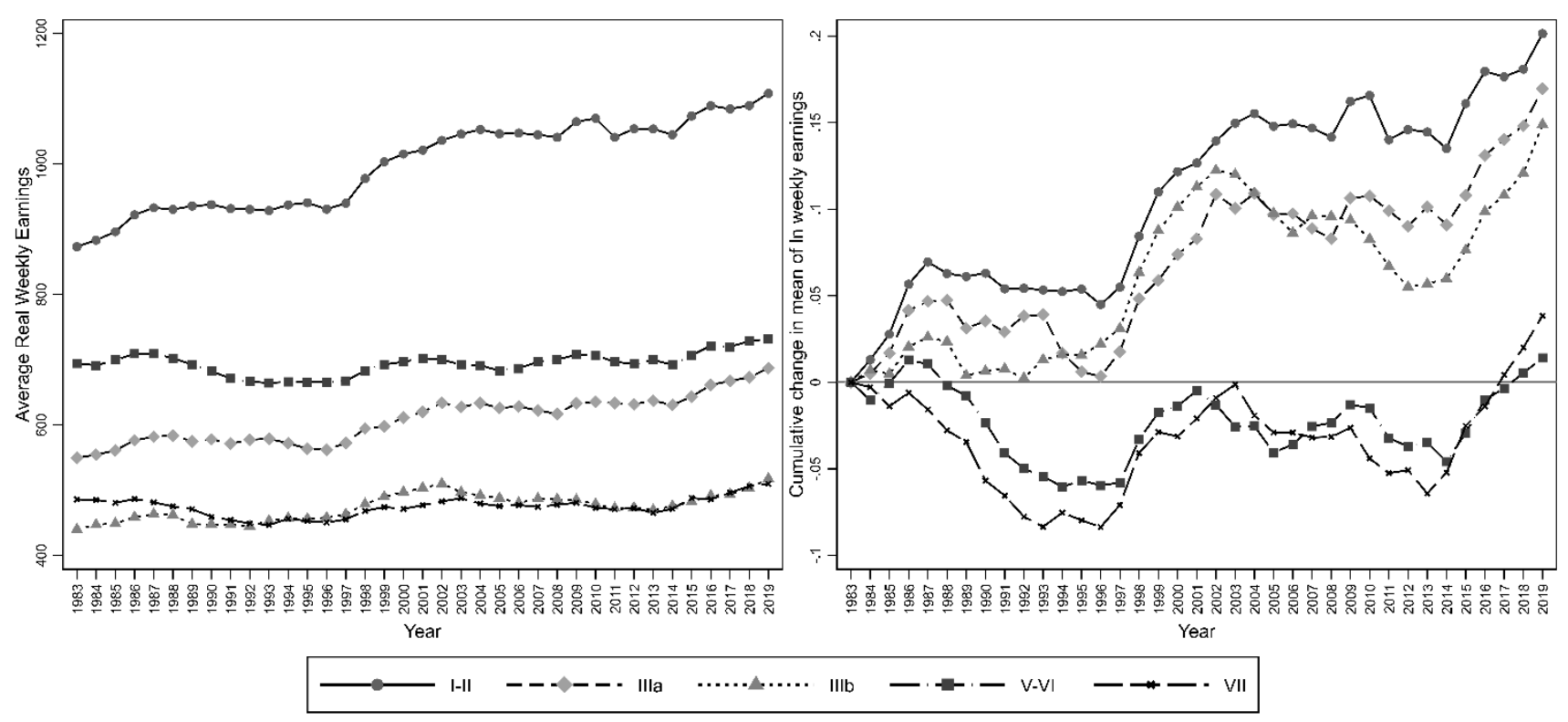

Notes: Figure reports trend in mean weekly earnings for five EGP classes. The left panel reports average weekly earnings; the right panel reports change in average ln weekly earnings from 1983. Values are adjusted to 2000 US dollars using CPI, and sampling weights are applied. Classes are the salariat (classes I-II), higher-level routine non-manual (classes IIIa), lower-level routine nonmanual (classes IIIb), skilled manual (classes V-VI) and unskilled manual (class VII). 
The right panel of figure 1 reports the cumulative change in the mean of the natural logarithm of weekly earnings for the five classes and gives a better depiction of the diverse growths in weekly earnings for each social class and thus in the evolution of between-class inequalities. The mean earnings of classes I-II, IIIa, and $\mathrm{IIIb}$ - those characterised by more significant monitoring difficulties - rose on average much more than manual classes V-VI and VII. An analysis of earnings growth in terms of the EGP class schema highlights a significant pattern of decreasing returns for manual workers (Classes VI and VII) in comparison to non-manual workers (Classes IIIa and IIIb) and, most notably, the salariat class (I-II).

Therefore, the critical question is which socio-economic transformations have altered the market position of different social classes driving the diverging earnings trajectories for these groups.

As mentioned above, socio-economic research has considered the decline in unions' power and increased reliance on information and communication technologies as the main factors behind the increase in earnings inequalities since the 1980s. Figures 2 and 3 give a first stylised, albeit highly informative, description of the relation of these two factors and the change in earnings for the four different social classes.

Figure 2 Relationship between industry-level change in union density and social class earnings 1984-2019
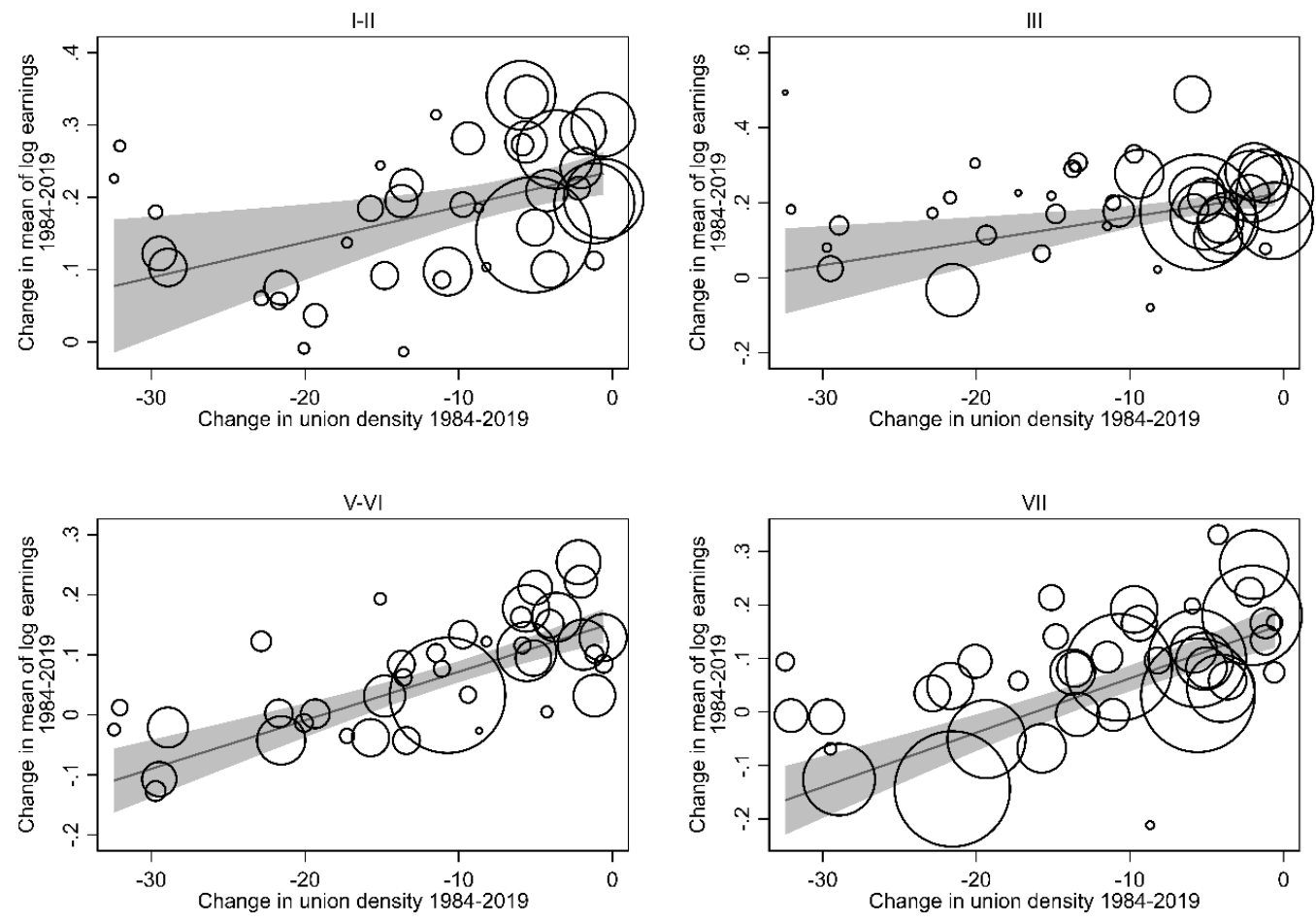

Notes: the relationship between 1984-2019 industry-level change in union density and 1984-2019 change in average ln of weekly earnings by social class. Aggregate statistics are computed using sampling weights. Circle size indicates the 2019 industry-class employment size. Classes are the salariat (classes I-II), routine nonmanual (classes IIIab), skilled manual (classes V-VI) and unskilled manual (class VII). 

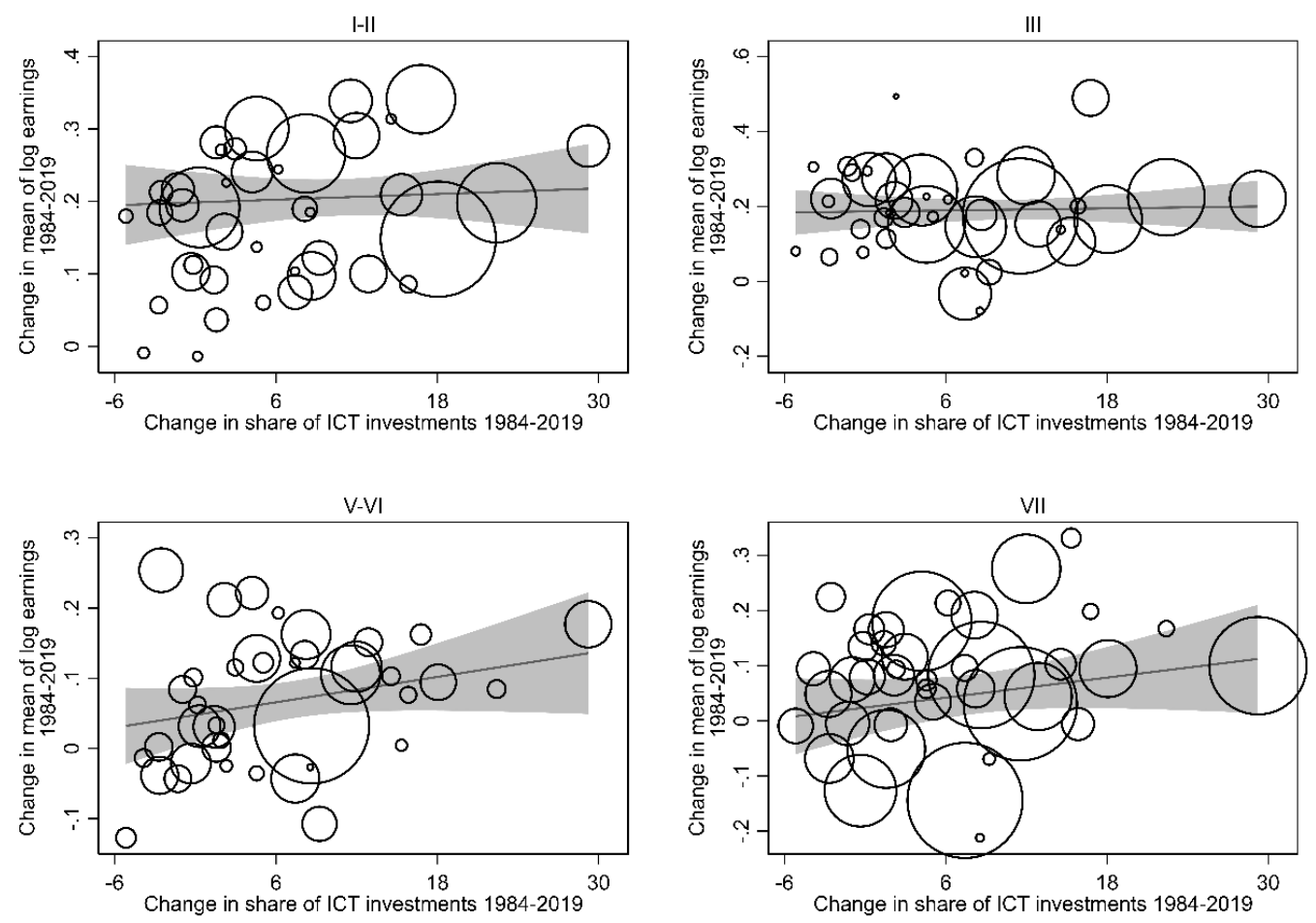

Notes: the relationship between 1984-2019 industry-level change in ICT investments and 1984-2019 change in In of weekly earnings by social class. Aggregate statistics are computed using sampling weights. Circle size indicates the 2019 industry-class employment size. Classes are the salariat (classes I-II), routine non-manual (classes IIIab), skilled manual (classes V-VI) and unskilled manual (class VII).

Figure 2 shows the relation between the change in industry level union density over 1984-2019 and the change in the mean of ln weekly earnings for each social class. Each industry-class combination was weighted by the total employment in 2019. Two facts emerge from this figure. First, earnings for all classes have grown the most in industries that experienced only limited union density decline (in many cases because they had low levels of union density to start with, see figure A1 in the appendix). Second, it emerges that a larger share of workers from manual classes (V-VI and VII) are employed in industries that experienced strong processes of de-unionisation compared to service classes (this evidence emerges regardless of the time point taken into consideration for the distribution of employment, see figure A2 in the appendix). Overall, figure 2 suggests that industry-level de-unionisation has been a relevant factor for the fortunes of all social classes, but lower manual classes have been the most exposed to the phenomena.

The same figure considering investments in ICT is reported in Figure 3. Contrary to de-unionisation, no clear pattern emerges, highlighting little or no relation between industry reliance on new technologies and earnings of different social classes.

Table 1 shows the results for Equation 1 estimated separately for each social class. All the socialdemographic controls enter the Equation with the expected sign. Most importantly, results in table 1 confirm the first conclusions drawn from descriptive figures 1 and 2: technological change appears to have had no 
relation to the earnings of all social classes while unionisation is positively related to earnings of social classes and more so for manual ones. Indeed, there is a substantive, relevant social class gradient in the relation between unionisation and earnings.

The same conclusions are evident from the ECMs in table 2, suggesting that variables non-stationarity does not influence the results from the first specification. The lag coefficient of technological change has a close to zero and non-significant effect on the earnings of all social classes, while unionisation exhibits once again a clear social class gradient.

The ECM further allows analysing the immediate effects given by the coefficients of the first differenced variable. Unionisation has an immediate positive effect on the earnings of all social classes except the salariat, while, as expected, investments in computer technologies have an immediate positive effect on the earnings of services classes only.

Table 1 Results for two-way fixed-effects models for EGP classes, the dependent variable is the mean of In weekly earnings

\begin{tabular}{|c|c|c|c|c|c|c|c|c|}
\hline \multirow{2}{*}{$\begin{array}{l}\text { Class } \\
\text { VARIABLES }\end{array}$} & \multicolumn{2}{|c|}{ I-II } & \multicolumn{2}{|l|}{ III } & \multicolumn{2}{|c|}{$\mathrm{V}-\mathrm{VI}$} & \multicolumn{2}{|c|}{ VII } \\
\hline & Coef & se & Coef & se & Coef & se & Coef & se \\
\hline ICT investments & 0.0002 & $(0.0003)$ & 0.0005 & $(0.0006)$ & -0.0005 & $(0.0006)$ & -0.0002 & $(0.0005)$ \\
\hline Union density & $0.0019 * * *$ & $(0.0006)$ & $0.0034 * * *$ & $(0.0012)$ & $0.0044 * * *$ & $(0.0008)$ & $0.0050 * * *$ & $(0.0008)$ \\
\hline Share of high-educated & $0.0032 * * *$ & $(0.0003)$ & $0.0046 * * *$ & $(0.0004)$ & $0.0029 * * *$ & $(0.0006)$ & $0.0042 * * *$ & $(0.0009)$ \\
\hline Share of female & $-0.0019 * * *$ & $(0.0005)$ & $-0.0027 * * *$ & $(0.0003)$ & $-0.0009 * *$ & $(0.0004)$ & $-0.0029 * * *$ & $(0.0005)$ \\
\hline Share of white non-Hispanic & 0.0004 & $(0.0005)$ & 0.0004 & $(0.0004)$ & $0.0009 * *$ & $(0.0003)$ & $0.0012 * *$ & $(0.0006)$ \\
\hline Average age & $0.0085^{* * *}$ & $(0.0017)$ & $0.0057 * *$ & $(0.0024)$ & $0.0082 * * *$ & $(0.0021)$ & 0.0019 & $(0.0015)$ \\
\hline Ln of real VA & 0.0048 & $(0.0096)$ & -0.0196 & $(0.0120)$ & -0.0036 & $(0.0130)$ & -0.0159 & $(0.0120)$ \\
\hline Mean ln Earning t-1 & $0.2866^{* * *}$ & $(0.0391)$ & $0.1770 * * *$ & $(0.0579)$ & $0.2807 * * *$ & $(0.0441)$ & $0.4047 * * *$ & $(0.0751)$ \\
\hline Year fixed effects & \multicolumn{2}{|c|}{ Yes } & \multicolumn{2}{|c|}{ Yes } & \multicolumn{2}{|c|}{ Yes } & \multicolumn{2}{|c|}{ Yes } \\
\hline Observations & 1,440 & & 1,440 & & 1,440 & & 1,440 & \\
\hline R-squared & 0.6731 & & 0.6067 & & 0.4521 & & 0.5381 & \\
\hline Number of ids & 40 & & 40 & & 40 & & 40 & \\
\hline
\end{tabular}

Tables A6 and A7 in the appendix show the results for the two models, including an interaction term between investments in ICT and union density, to investigate possible moderating effects. Coefficients for all covariates are almost identical to the main specification, but the interaction term is statistically non-significant and approximates zero. Thus, results do not support the idea of a moderating relationship between the two variables.

As mentioned above, the straightforward interpretation of the functional effects estimated by models 1 and 2 is not fully informative about the overall contribution of each factor due to the dynamic nature of the models and the fact that workers in different classes are not equally distributed across industries. In fact, as figures 2 and 3 in the appendix highlight, a much larger share of manual workers was employed in industries 
that experienced strong de-unionisation since 1984. For example, in 2019, 73.4 and 83.6 per cent of employees in salariat and non-routine manual classes respectively were employed in industries that experienced less than a six-percentage point decline in union density against the 43.4 and 50.4 per cent of workers in skilled and non-skilled manual classes. As a result, one would expect unionisation to have had a more decisive contribution to the overall evolution in earnings of manual classes and, therefore, an essential role in explaining divergent earnings trajectories between the groups.

Figure 4 presents the estimated changes in the mean of ln weekly earnings for each social class for 19842019 over the total economy estimated from model one and holding covariates of interest to their 1984 levels (counterfactual forecasts for the whole period are presented in figure A4 appendix). Forecasts are estimated for each industry-class combination and then combined to represent the entire economy by taking the yearly averages weighted by each cell employment size. The results are counterfactual estimates of each class earnings growth had industry levels covariates remained at 1984.

Table 2 Results for fixed-effects ECMs for EGP classes, the dependent variable is the mean of In weekly earnings

\begin{tabular}{|c|c|c|c|c|c|c|c|c|}
\hline Class & I-II & & III & & $\mathrm{V}-\mathrm{VI}$ & & VII & \\
\hline VARIABLES & Coef & se & Coef & se & Coef & se & Coef & se \\
\hline L. ICT investments & 0.0001 & $(0.0003)$ & 0.0004 & $(0.0005)$ & -0.0005 & $(0.0006)$ & -0.0002 & $(0.0004)$ \\
\hline$\Delta \mathrm{ICT}$ investments & $0.0017 * *$ & $(0.0008)$ & $0.0023 * *$ & $(0.0009)$ & 0.0008 & $(0.0011)$ & 0.0006 & $(0.0013)$ \\
\hline L.Union density & $0.0018 * *$ & $(0.0007)$ & $0.0029 * *$ & $(0.0012)$ & $0.0042 * * *$ & $(0.0009)$ & $0.0048^{* * *}$ & $(0.0010)$ \\
\hline$\Delta$ Union density & 0.0007 & $(0.0010)$ & $0.0037 * * *$ & $(0.0013)$ & $0.0038 * * *$ & $(0.0012)$ & $0.0049 * * *$ & $(0.0011)$ \\
\hline L.Share of high-edu & $0.0026 * * *$ & $(0.0005)$ & $0.0045^{* * *}$ & $(0.0009)$ & $0.0027 * * *$ & $(0.0006)$ & $0.0029 * * *$ & $(0.0008)$ \\
\hline$\Delta$ Share of high-edu & $0.0035 * * *$ & $(0.0004)$ & $0.0045^{* * *}$ & $(0.0004)$ & $0.0031 * * *$ & $(0.0006)$ & $0.0043 * * *$ & $(0.0010)$ \\
\hline L.Share of female & $-0.0013 * *$ & $(0.0006)$ & $-0.0022 * * *$ & $(0.0005)$ & -0.0003 & $(0.0006)$ & $-0.0031 * * *$ & $(0.0009)$ \\
\hline$\Delta$ Share of female & $-0.0020 * * *$ & $(0.0005)$ & $-0.0028 * * *$ & $(0.0003)$ & $-0.0010 * *$ & $(0.0005)$ & $-0.0027 * * *$ & $(0.0004)$ \\
\hline L.Average age & $0.0060 * * *$ & $(0.0015)$ & $0.0057 * *$ & $(0.0026)$ & $0.0059 *$ & $(0.0034)$ & -0.0027 & $(0.0022)$ \\
\hline$\Delta$ Average age & $0.0111 * * *$ & $(0.0017)$ & $0.0059 * *$ & $(0.0028)$ & $0.0100 * * *$ & $(0.0014)$ & $0.0034 *$ & $(0.0017)$ \\
\hline L.Share of white & 0.0002 & $(0.0006)$ & -0.0004 & $(0.0005)$ & 0.0006 & $(0.0005)$ & 0.0005 & $(0.0005)$ \\
\hline$\Delta$ Share of white & 0.0004 & $(0.0004)$ & 0.0007 & $(0.0005)$ & $0.0012 * * *$ & $(0.0003)$ & $0.0017 * *$ & $(0.0006)$ \\
\hline L.Log of real value added & 0.0084 & $(0.0087)$ & -0.0156 & $(0.0123)$ & -0.0011 & $(0.0116)$ & -0.0105 & $(0.0119)$ \\
\hline$\Delta$ Log of real value added & 0.0051 & $(0.0233)$ & $-0.0399 *$ & $(0.0233)$ & 0.0060 & $(0.0375)$ & -0.0355 & $(0.0247)$ \\
\hline L.Mean log earnings & $-0.6658 * * *$ & $(0.0405)$ & $-0.8110 * * *$ & $(0.0854)$ & $-0.6899 * * *$ & $(0.0582)$ & $-0.5682 * * *$ & $(0.0805)$ \\
\hline Year fixed effects & \multicolumn{2}{|c|}{ Yes } & \multicolumn{2}{|c|}{ Yes } & \multicolumn{2}{|c|}{ Yes } & \multicolumn{2}{|c|}{ Yes } \\
\hline Observations & \multicolumn{2}{|l|}{1,400} & \multicolumn{2}{|l|}{1,400} & \multicolumn{2}{|l|}{1,400} & \multicolumn{2}{|l|}{1,400} \\
\hline R-squared & \multicolumn{2}{|l|}{0.5052} & \multicolumn{2}{|l|}{0.5568} & \multicolumn{2}{|l|}{0.4587} & \multicolumn{2}{|l|}{0.4187} \\
\hline Number of ids & \multicolumn{2}{|l|}{40} & \multicolumn{2}{|l|}{40} & \multicolumn{2}{|l|}{40} & \multicolumn{2}{|l|}{40} \\
\hline
\end{tabular}

Cluster robust standard errors at the industry level in parentheses; $* * * \mathrm{p}<0.01, * * \mathrm{p}<0.05,{ }^{*} \mathrm{p}<0.1$;

The first bar of each box represents the actual earnings growth for each social class are reported in figure 1. The other bars represent the estimated change had union density, computerisation, and share of tertiary educated remained constant. Differences between the observed earnings change and the counterfactual estimates can thus be interpreted as the total long-term contribution of each factor to the earnings development 
of each class. Particular attention is paid to educational level other than industry level covariates since skills are considered among the main determinants of social-class earnings, and increases in educational returns are considered the main driving forces of earnings inequalities.

Looking at the change in earnings related to de-unionisation, figure 4 highlights that the earnings growth for classes I-II and III would have been almost identical had unionisation remained at its original levels. On the contrary, the decline in union density is the only substantively relevant factor for manual classes. Furthermore, investments in computer technologies do not emerge as a relevant factor for any of the classes analysed, contrary to the increase in tertiary-educated workers, which explains a considerable part of the earnings growth of the salariat classes and almost the entirety for routine non-manual workers.

\section{Figure 4 Counterfactual estimates of 1984-2019 earnings growth for EGP classes}
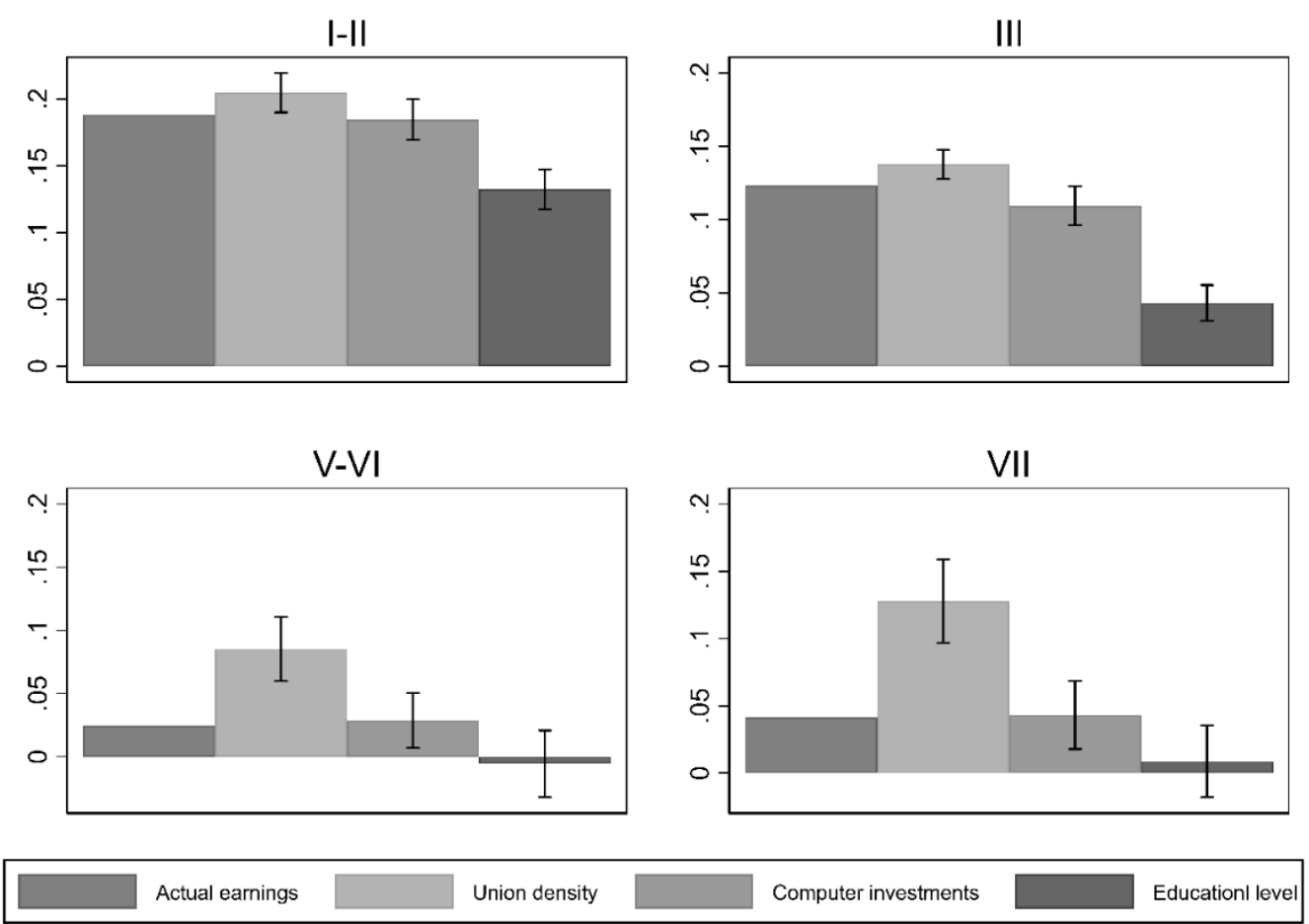

Notes: 1984-2019 change in observed and counterfactual dynamic estimates predicted from model 1 using bootstrapped standard errors and holding values of the dependent variables at their 1984 levels. Details of the procedure and change in forecasts for the entire period are available in the appendix section "Counterfactual estimates." Classes are the salariat (classes I-II), routine non-manual (classes IIIab), skilled manual (classes V-VI) and unskilled manual (class VII).

\section{Conclusions}

The present article has investigated the contribution of de-unionization and computerization at the industry level to the evolution of earnings of different social classes in the US from 1984 to 2019. Socio-economic literature has repeatedly shown that overall earnings inequalities in this period have grown and that betweenoccupations inequalities have been an essential dimension of this process. 
The main narrative, promoted by mainstream economic literature, suggested that technological change has been the most crucial cause of rising inequalities. Most importantly, the theory of RBTC extended this claim to explain diverse earnings growth between occupations and eventually social classes. By claiming that technological change since the 1970s was a good substitute for routine tasks and middle-class workers mainly performing these tasks, RBTC suggested that the increased reliance on computerized equipment was responsible for the observed hollowing out of the middle-classes and the so-called middle-class squeeze.

Sociological literature, however, has questioned this assumption suggesting that institutions and the bargaining power of different groups and classes matter. As a result, several empirical studies have shown that other factors, such as the fall of union density, minimum wages and financialization, have played a significant role in the growth of earnings inequalities in terms of overall dispersion of earnings or functional distribution of income, often much more than technological change.

This article confirms this conclusion in regards to inequalities between social classes. Indeed, tasks and occupation are a crucial dimension in the definition of social classes and play a crucial role in economic returns beyond their susceptibility or complementarity to technological change. Literature on social stratification and mobility has traditionally highlighted that the tasks performed, in terms of monitorability and asset specificity, are strictly related to workers' social class and, eventually, economic returns.

While technological change is a relevant factor in determining the demand for specific tasks and the degree of monitorability of others, it is not the only one. On the contrary, the industry-level decline in union density appears a crucial factor behind the diverging fortunes of manual and non-manual workers.

An observation of the earnings levels and growth of four different EGP classes has highlighted that earnings are associated with social class and that this association has changed over the last decades. More precisely, earnings of the salariat and routine non-manual workers have grown while those of skilled and unskilled manual workers have either stagnated or declined.

Both descriptive statistics and econometric analysis suggested that industry-level investments in computer technologies have had a negligible impact on the earnings growth of all social classes in the period considered, casting doubts on the theories of routine and skilled biased technological change. However, it must be noted that conclusions are limited to the industry-level relation, that is, the effect of industrial computerization on workers employed in that industry. Nevertheless, technological change may have an effect beyond the industry in which it is implemented, for instance, by raising demand for workers in specific classes. Nevertheless, both RBTC and SBTC suggest a relation between technology and earnings related to the complementarity between computers and skills. It follows that a positive association between the two should be most evident in industries that invest extensively in computer technologies.

On the other hand, union density emerged as a crucial factor behind the diverse earnings growth of the different classes in two ways. First, union density is positively associated with the earnings of all classes but more so for non-salariat ones. This finding confirms recent literature suggesting that unions increase average wages for all groups of workers through several mechanisms-such as unionization threat, the promotion of a 
moral economy, and social comparison. However, benefits are more pronounced for blue-collar and lessskilled workers who cannot bargain higher wages based on their market position.

Second, the decline in union density had played a significant role for skilled and unskilled manual workers due to their higher exposure to the phenomena. In fact, during the period analysed, a much large share of classes V-VI and VII were employed in industries that experienced significant declines in union density compared to classes I-II and III. As a result, manual workers have been much more influenced by deunionization.

Interestingly, the results do not confirm the presence of a mediating or moderating role of unionization in the relationship between technological change and the earnings of each social class in the period under consideration. This finding is not in line with a growing body of research that has stressed the two phenomena' interrelatedness. However, it must be noted that this result is confined to the observation of between class inequalities at the industry level. On the other hand, the two macro factors may interact in their relationship to overall earnings dispersion, labour's share, or inequalities defined by cleavages other than social class. Moreover, the interrelatedness between two factors may play out at other levels of analysis, such as the national level or in the relationship between industries.

Finally, results have highlighted the importance of different skill levels between classes in terms of the share of tertiary-educated workers. Despite technological change, the average share of tertiary-educated workers emerged as a positive factor for all classes. However, the increase in educational level has been pronounced only for non-manual workers who consequently benefitted the most. This result echoes Tahlin (2007) suggestion that occupational skill requirements may be among the strongest justifications for between social classes disparities, and the more robust increase in human capital for service classes has contributed to the divergent growth in earnings. 


\section{References}

Acemoglu D., Aghion P., Violante G. (2001) Deunionization, technical change and inequality, CarnegieRochester Conference Series on Public Policy 55 (2001) 229-264

Akerlof, G. A. (1984). Gift exchange and efficiency-wage theory: Four views. The American Economic Review, 74(2), $79-83$.

Alderson, A. S., \& Katz-Gerro, T. (2016). Compared to whom? Inequality, social comparison, and happiness in the United States. Social Forces, 95(1), 25 - 54.

Autor, D. H., Levy, F., \& Murnane, R. J. (2003). The Skill Content of Recent Technological Change: an Empirical Explorations. The Quarterly Journal of Economics, 118(4), 1279 - 1333.

Berman, E., Bound, J., \& Griliches, Z. (1994). Changes in the demand for skilled labor within U.S. manufacturing industries: evidence from the Annual Survey of Manufacturing. Quarterly Journal of Economics , 109, 367-397.

Blau, F.D. \& Kahn, L. (2009) Inequality and earnings distribution, in Wiemer Salverda, Brian Nolan \& Timothy M. Smeeding (eds.), The Oxford Handbook of Economic Inequality. Oxford University Press

Brady, D., Baker, R. S., \& Finnigan, R. (2013). When unionization disappears: State-level unionization and working poverty in the United States. American Sociological Review, 78(5), 872 - 896.

Braverman, H. (1974). Labor and Monopoly Capital: The Degradation of Work in the Twentieth Century. Monthly Review Press.

Breen, R. (2005). Foundations of a neo-Weberian class analysis. Approaches to Class Analysis, 31 - 50.

Card, D., Lemieux, T., \& Riddell, W. C. (2017). Unions and wage inequality. In What Do Unions Do? (pp. 114 - 159). Routledge.

Checchi D. \& Lucifora C. (2002) Unions and labour market institutions in Europe, Economic Policy October 2002

Checchi D., García-Peñalosa C., Petrongolo B. and Zweimüller J. (2008) Labour Market Institutions and Income Inequality, Economic Policy, Vol. 23, No. 56

De Boef, S., \& Keele, L. (2008). Taking time seriously. American Journal of Political Science, 52(1), 184 200.

Denice, P., \& Rosenfeld, J. (2018). Unions and Nonunion Pay in the United States, 1977-2015. Sociological Science, 5, $541-561$.

DiNardo, J., Fortin, N. M., \& Lemieux, T. (1996). Labor market institutions and the distribution of wages, 1973-1992: A semiparametric approach. Econometrica: Journal of the Econometric Society, 1001 1044.

Edlund, J., \& Lindh, A. (2015). The democratic class struggle revisited: The welfare state, social cohesion and political conflict. Acta Sociologica, 58(4), $311-328$.

Elsby, M. W. L., Hobijn, B., \& Şahin, A. (2013). The decline of the US labor share. Brookings Papers on Economic Activity, 2013(2), 1 - 63.

Erikson, R., \& Goldthorpe, J. H. (1992). The Constant Flux: A Study of Class Mobility in Industrial Societies. Oxford University Press.

Erikson, R., Goldthorpe, J. H. and Portocarero, L. (1979). Intergenerational Class Mobility in Three Western European Societies: England, France, and Sweden. British Journal of Sociology, 30, 415 - 441.

Evans, G. (1992). Testing the validity of the Goldthorpe class schema. European Sociological Review, 8(3), $211-232$. 
Evans, G. (2000). The continued significance of class voting. Annual Review of Political Science, 3(1), $401-$ 417.

Flood, S., King, M., Rodgers, R., Ruggles, S., \& Robert, W. J. (2020). Integrated Public Use Microdata Series, Current Population Survey: Version 8.0 [dataset]. IPUMS.

Freeman, R. B. (1980). Unionism and the Dispersion of Wages. ILR Review, 34(1), 3 - 23.

Freeman, R. B. (1984). Longitudinal analyses of the effects of trade unions. Journal of Labor Economics, $2(1), 1-26$.

Freeman, R. B. (2005). What Do Unions Do? Journal of Labor Research, 26(4), 641 - 668. https://doi.org/10.1007/s12122-005-1003-7

Goedemé, T., Paskov, M., Weisstanner, D., \& Nolan, B. (2020). Social class and earnings: a cross-national study. INET Oxford Working Paper.

Goldin, C., Katz, L. (1998). The origins of technology-skill complementarity. Quarterly Journal of Economics, 113, 693-732.

Goldin, C., \& Katz, L. (2007). The Race between Education and Technology: The Evolution of U.S. Educational Wage Differentials 1890 to 2005. NBER Working Paper No.12984, Cambridge, National Bureau of Economic Research.

Goldthorpe, J. H. (2000). Social Class and the Differentiation of Employment Contracts. In Goldthorpe, J. H. On Sociology: Numbers, Narratives, and the Integration of Research and Theory. Oxford University Press, pp. $206-229$.

Goldthorpe, J. H., \& McKnight, A. (2006). The Economic Basis of Social Class. In M. S., D. B. Grusky, \& F. G. S. (Eds.), Mobility and Inequality: Frontiers of Research from Sociology and Economics (pp. 109 - 136). CA: Stanford University Press.

Grimshaw D., Bosch G., Rubery J. (2014). Minimum wages and collective bargaining: What types of pay bargaining can foster positive pay equity outcomes? British Journal of Industrial Relations, 52(3), pp. 470-498

Guy, F., \& Skott, P. (2013). Technology, power and the political economy of inequality (No. 162; Economics Department Working Paper Series).

Guy, F., \& Skott, P. (2015). Technology, power and the political economy of inequality. In Research Handbook on Political Economy and Law. Edward Elgar Publishing.

Hunter, L. W., \& Lafkas, J. J. (2003). Opening the box: Information technology, work practices, and wages. ILR Review, 56(2), $224-243$.

IPUMS USA. (2018). Integrated Occupation and Industry Codes and Occupational Standing Variables In The IPUMS. Minnesota Population Center. https://usa.ipums.org/usa/chapter4/chapter4.shtml.

Jacobs, D., \& Dirlam, J. C. (2016). Politics and economic stratification: Power resources and income inequality in the United States. American Journal of Sociology, 122(2), $469-500$.

Kim, C., \& Sakamoto, A. (2008). The rise of intra-occupational wage inequality in the United States, 1983 to 2002. American Sociological Review, 73(1), 129 - 157.

Kristal, T. (2013). The Capitalist Machine: Computerization, Workers' Power, and the Decline in Labor's Share within U. S. Industries. American Sociological Review, 78(3), 361 - 389. https://doi.org/10.1177/0003122413481351

Kristal, T. (2020). Why Has Computerization Increased Wage Inequality? Information, Occupational Structural Power, and Wage Inequality. Work and Occupations, 47(4), 466 - 503.

Kristal, T., \& Cohen, Y. (2015). What do computers really do? Computerization, fading pay-setting institutions and rising wage inequality. Research in Social Stratification and Mobility, 42, $33-47$. 
Kristal, T., \& Cohen, Y. (2017). The causes of rising wage inequality : the race between institutions and technology. Socio-Economic Review, 15(1), 187 - 212. https://doi.org/10.1093/ser/mww006

Kristal, T. (2019). Computerization and the Decline of American Unions: Is Computerization ClassBiased?. Work and Occupations, 46(4), 371-410.

Krueger, A., (1993). How computers have changed the wage structure: evidence from micro data 1984-1989, Quarterly Journal of Economics, 108, 33-60.

Le Grand, C., \& Tåhlin, M. (2013). Class, occupation, wages, and skills: The iron law of labor market inequality. In Class and stratification analysis. Emerald Group Publishing Limited.

Leicht, K. T. (1989). On the estimation of union threat effects. American Sociological Review, 1035 - 1047.

Levy, F., \& Murnane, R. J. (1992). US earnings levels and earnings inequality: A review of recent trends and proposed explanations. Journal of Economic Literature, 30(3), 1333 - 1381.

Lin, K.-H., \& Tomaskovic-Devey, D. (2013). Financialization and US income inequality, 1970 - 2008. American Journal of Sociology, 118(5), 1284 - 1329.

Lipset, S. M. (1960). Political man: the social bases af politics. Doubleday.

Maxwell, N. L. (2008). Wage differentials, skills, and institutions in low-skill jobs. ILR Review, 61(3), 394 409.

McCall, L., \& Percheski, C. (2010). Income inequality: New trends and research directions. Annual Review of Sociology, 36, $329-347$.

Menon, S., Salvatori, A., \& Zwysen, W. (2019). The Effect of Computer Use on Work Discretion and Work Intensity: Evidence from Europe. British Journal of Industrial Relations.

Mishel, L., Bivens, J., Gould, E., \& Shierholz, H. (2012). The state of working America. Cornell University Press.

Morgan, S. L. (2017). A coding of social class for the general social survey. Chicago, Illinois: GSS Methodological Report, 125.

Morgan, S. L., \& McKerrow, M. W. (2004). Social class, rent destruction, and the earnings of black and white men, 1982 - 2000. Research in Social Stratification and Mobility, 21, 215 - 251.

Morgan, S. L., \& Tang, Z. (2007). Social class and workers' rent, 1983 - 2001. Research in Social Stratification and Mobility, 25(4), 273 - 293.

Mouw, T., \& Kalleberg, A. L. (2010). Occupations and the Structure of Wage Inequality in the United States, 1980s to 2000s. American Sociological Review, 75(3), 402 - 431.

Parolin, Z. (2021). Automation, occupational earnings trends, and the moderating role of organized labor. Social Forces, 99(3), $921-946$.

Piketty, T., \& Saez, E. (2003). Income inequality in the United States, 1913 - 1998. The Quarterly Journal of Economics, 118(1), 1 - 41.

Rosenfeld, J. (2006). Widening the gap: The effect of declining unionization on managerial and worker pay, 1983 - 2000. Research in Social Stratification and Mobility, 24(3), 223 - 238.

Schmitt, J. (2003). Creating a consistent hourly wage series from the Current Population Survey's Outgoing Rotation Group, 1979-2002. Version 0.9 (August). Washington DC: Center for Economic and Policy Research.

Scopp, T. S. (2003). The relationship between the 1990 census and census 2000 industry and occupation classification systems.

Skott, P., \& Guy, F. (2007). A model of power-biased technological change. Economics Letters, 95(1), 124 - 
131.

Tåhlin, M. (2007). Class clues. European Sociological Review, 23(5), 557 - 572.

U.S. Census Bureau. (2013). 1990-2012 Census Industry Codes with Crosswalk. https://www.census.gov/topics/employment/industry-occupation/guidance/code-lists.html

VanHeuvelen, T. (2018). Moral economies or hidden talents? A longitudinal analysis of union decline and wage inequality, 1973 - 2015. Social Forces, 97(2), $495-530$.

Weeden, K. A., Kim, Y.-M., Di Carlo, M., \& Grusky, D. B. (2007). Social class and earnings inequality. American Behavioral Scientist, 50(5), 702 - 736.

Western, B., \& Rosenfeld, J. (2011). Unions, norms, and the rise in US wage inequality. American Sociological Review, 76(4), 513 - 537.

Wilkinson, R., \& Pickett, K. (2011). The spirit level: Why greater equality makes societies stronger. Bloomsbury Publishing USA.

Wright, E. O. (1997). Class counts: Comparative studies in class analysis. Cambridge University Press.

Wright, E. O. (2005). Approaches to class analysis. Cambridge University Press.

Zhou, X., \& Wodtke, G. T. (2019). Income stratification among occupational classes in the United States. Social Forces, 97(3), $945-972$. 
Table A1 Descriptive statistics industry-class panel 1984-2019

\begin{tabular}{|c|c|c|c|c|}
\hline Variables & Mean & SD. & Min & Max \\
\hline Computer investments & 12.3 & 11.4 & 0.2 & 68.5 \\
\hline Union density & 12.9 & 10.3 & 1.0 & 49.0 \\
\hline \multicolumn{5}{|l|}{ Mean of log earnings } \\
\hline$I-I I$ & 6.8 & 0.2 & 6.2 & 7.2 \\
\hline III & 6.2 & 0.2 & 5.6 & 6.8 \\
\hline$V-V I$ & 6.4 & 0.2 & 5.8 & 6.9 \\
\hline$V I I$ & 6.1 & 0.2 & 5.4 & 6.8 \\
\hline \multicolumn{5}{|l|}{ Share of tertiary educated } \\
\hline$I-I I$ & 59.1 & 13.7 & 17.7 & 92.0 \\
\hline III & 22.8 & 9.8 & 0.0 & 60.3 \\
\hline$V-V I$ & 16.1 & 10.6 & 0.0 & 62.4 \\
\hline VII & 5.6 & 4.5 & 0.0 & 35.0 \\
\hline \multicolumn{5}{|l|}{ Share of Female } \\
\hline$I-I I$ & 36.7 & 17.2 & 4.8 & 84.2 \\
\hline III & 64.7 & 13.1 & 23.3 & 95.9 \\
\hline$V-V I$ & 20.0 & 16.7 & 0.2 & 78.9 \\
\hline VII & 29.6 & 18.1 & 0.3 & 83.3 \\
\hline \multicolumn{5}{|l|}{ Average age } \\
\hline$I-I I$ & 41.3 & 2.8 & 30.1 & 49.3 \\
\hline III & 39.8 & 3.5 & 29.8 & 51.9 \\
\hline$V-V I$ & 40.3 & 3.1 & 29.3 & 52.1 \\
\hline$V I I$ & 39.5 & 3.2 & 30.5 & 50.8 \\
\hline \multicolumn{5}{|c|}{ Share of white non-Hispanic workers } \\
\hline$I-I I$ & 81.7 & 8.2 & 55.8 & 99.2 \\
\hline III & 75.0 & 11.0 & 44.3 & 100.0 \\
\hline$V-V I$ & 73.9 & 9.1 & 35.8 & 96.5 \\
\hline VII & 58.0 & 12.2 & 17.7 & 89.7 \\
\hline Log of real value added & 12.0 & 1.2 & 9.0 & 14.9 \\
\hline
\end{tabular}


Figure A1 Trends in computerisation, union density and social class earnings by broad industries (1984-2019)

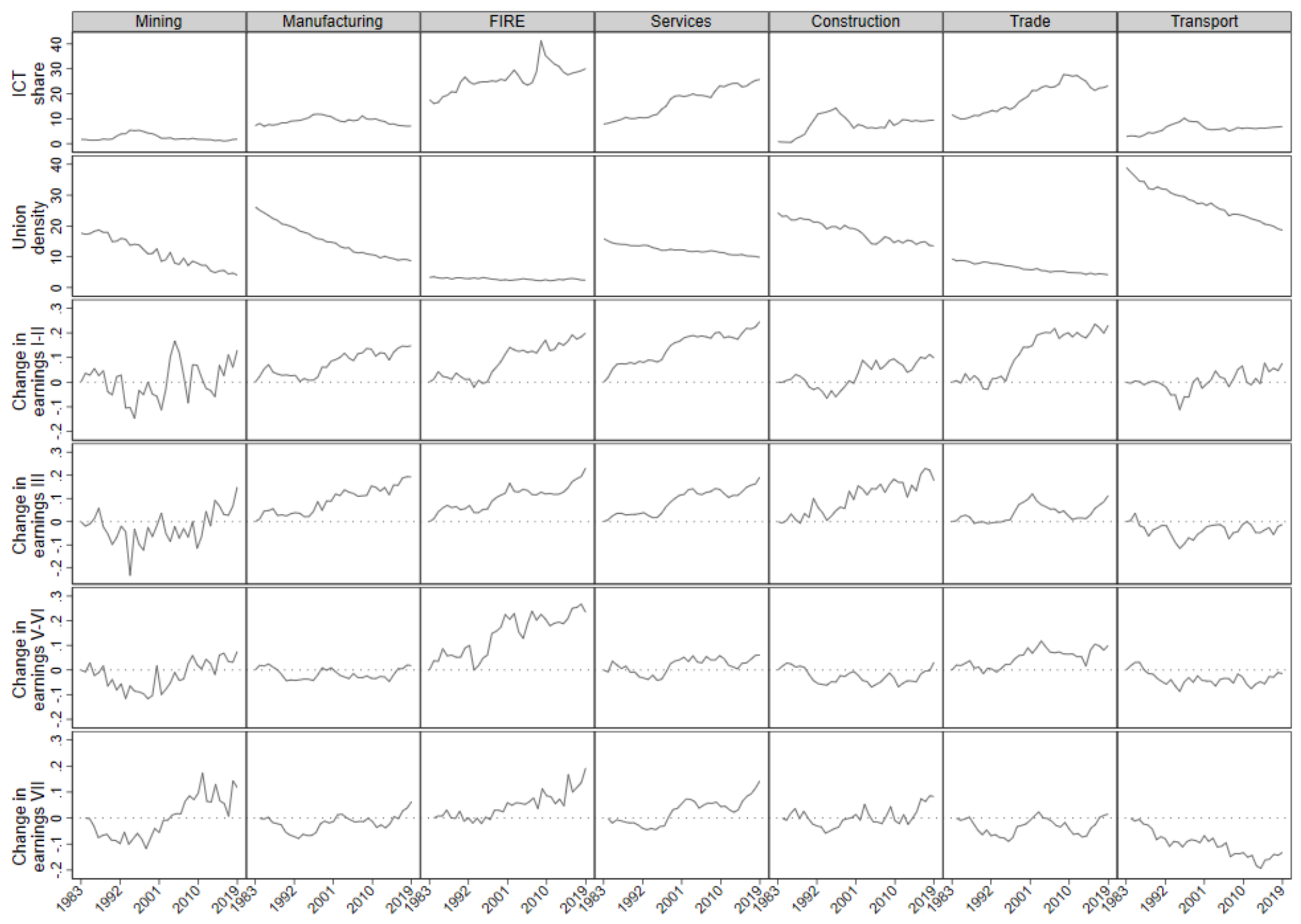


Table A2 Two-way fixed-effect models fully interacted by EGP classes (M1), robustness checks for top-codes (M2) and cell-size (M3-M5)

\begin{tabular}{|c|c|c|c|c|c|}
\hline VARIABLES & $\begin{array}{c}\text { M1 } \\
\text { Main model interacted }\end{array}$ & $\begin{array}{c}\text { M2 } \\
\text { Median earnings }\end{array}$ & $\begin{array}{c}M 3 \\
N>49\end{array}$ & $\begin{array}{c}\text { M4 } \\
\mathrm{N}>99\end{array}$ & $\begin{array}{c}\text { M5 } \\
\text { Weighted by average cell size }\end{array}$ \\
\hline ICT shares & $\begin{array}{c}0.0002 \\
(0.0003)\end{array}$ & $\begin{array}{c}0.0004 \\
(0.0004)\end{array}$ & $\begin{array}{c}0.0002 \\
(0.0003)\end{array}$ & $\begin{array}{c}0.0000 \\
(0.0003)\end{array}$ & $\begin{array}{c}0.0002 \\
(0.0003)\end{array}$ \\
\hline III*ICT shares & $\begin{array}{c}0.0003 \\
(0.0005)\end{array}$ & $\begin{array}{c}0.0002 \\
(0.0007)\end{array}$ & $\begin{array}{c}0.0002 \\
(0.0004)\end{array}$ & $\begin{array}{c}0.0002 \\
(0.0004)\end{array}$ & $\begin{array}{l}-0.0002 \\
(0.0004)\end{array}$ \\
\hline V-VI*ICT shares & $\begin{array}{l}-0.0007 \\
(0.0006)\end{array}$ & $\begin{array}{l}-0.0007 \\
(0.0007)\end{array}$ & $\begin{array}{l}-0.0007 \\
(0.0006)\end{array}$ & $\begin{array}{l}-0.0006 \\
(0.0006)\end{array}$ & $\begin{array}{l}-0.0004 \\
(0.0006)\end{array}$ \\
\hline VII*ICT shares & $\begin{array}{l}-0.0004 \\
(0.0005)\end{array}$ & $\begin{array}{l}-0.0005 \\
(0.0006)\end{array}$ & $\begin{array}{l}-0.0006 \\
(0.0005)\end{array}$ & $\begin{array}{l}-0.0007 * \\
(0.0004)\end{array}$ & $\begin{array}{l}-0.0002 \\
(0.0004)\end{array}$ \\
\hline Union density & $\begin{array}{l}0.0019^{* * *} \\
(0.0006)\end{array}$ & $\begin{array}{c}0.0023 * * * \\
(0.0008)\end{array}$ & $\begin{array}{c}0.0021 * * * \\
(0.0006)\end{array}$ & $\begin{array}{l}0.0020^{* * * *} \\
(0.0005)\end{array}$ & $\begin{array}{c}0.0018^{* * * *} \\
(0.0005)\end{array}$ \\
\hline III*Union density & $\begin{array}{c}0.0014 \\
(0.0010)\end{array}$ & $\begin{array}{c}0.0020 \\
(0.0012)\end{array}$ & $\begin{array}{c}0.0018^{* *} \\
(0.0009)\end{array}$ & $\begin{array}{c}0.0022 * * \\
(0.0008)\end{array}$ & $\begin{array}{l}0.0013^{*} \\
(0.0008)\end{array}$ \\
\hline $\mathrm{V}-\mathrm{VI} *$ Union density & $\begin{array}{l}0.0024 * * \\
(0.0010)\end{array}$ & $\begin{array}{l}0.0031^{* *} \\
(0.0012)\end{array}$ & $\begin{array}{l}0.0019^{* *} \\
(0.0009)\end{array}$ & $\begin{array}{l}0.0024 * * * \\
(0.0008)\end{array}$ & $\begin{array}{c}0.0024 * * * \\
(0.0008)\end{array}$ \\
\hline VII*Union density & $\begin{array}{l}0.0031 * * * \\
(0.0008)\end{array}$ & $\begin{array}{l}0.0044 * * * \\
(0.0010)\end{array}$ & $\begin{array}{c}0.0024 * * * \\
(0.0009)\end{array}$ & $\begin{array}{c}0.0023 * * \\
(0.0009)\end{array}$ & $\begin{array}{l}0.0028 * * * \\
(0.0006)\end{array}$ \\
\hline Share of high educated & $\begin{array}{l}0.0032 * * * \\
(0.0003)\end{array}$ & $\begin{array}{c}0.0035^{* * *} \\
(0.0005)\end{array}$ & $\begin{array}{c}0.0031 * * * \\
(0.0003)\end{array}$ & $\begin{array}{c}0.0032^{* * * *} \\
(0.0005)\end{array}$ & $\begin{array}{c}0.0025^{* * * *} \\
(0.0004)\end{array}$ \\
\hline III*Share of high educated & $\begin{array}{c}0.0013 * * \\
(0.0005)\end{array}$ & $\begin{array}{c}0.0011 \\
(0.0009)\end{array}$ & $\begin{array}{c}0.0010^{* *} \\
(0.0005)\end{array}$ & $\begin{array}{c}0.0003 \\
(0.0007)\end{array}$ & $\begin{array}{l}-0.0000 \\
(0.0006)\end{array}$ \\
\hline $\mathrm{V}-\mathrm{VI} *$ Share of high educated & $\begin{array}{c}-0.0003 \\
(0.0005)\end{array}$ & $\begin{array}{c}-0.0009 \\
(0.0008)\end{array}$ & $\begin{array}{l}-0.0002 \\
(0.0005)\end{array}$ & $\begin{array}{c}0.0001 \\
(0.0008)\end{array}$ & $\begin{array}{c}0.0001 \\
(0.0006)\end{array}$ \\
\hline VII*Share of high educated & $\begin{array}{c}0.0010 \\
(0.0010)\end{array}$ & $\begin{array}{c}0.0002 \\
(0.0013)\end{array}$ & $\begin{array}{c}0.0006 \\
(0.0012)\end{array}$ & $\begin{array}{c}-0.0019 * \\
(0.0011)\end{array}$ & $\begin{array}{c}-0.0001 \\
(0.0009)\end{array}$ \\
\hline Share of female & $\begin{array}{c}-0.0019 * * * \\
(0.0005)\end{array}$ & $\begin{array}{c}-0.0026^{* * *} * \\
(0.0006)\end{array}$ & $\begin{array}{c}-0.0018^{* * * *} \\
(0.0005)\end{array}$ & $\begin{array}{c}-0.0015^{* * *} * \\
(0.0005)\end{array}$ & $\begin{array}{c}-0.0014^{* * *} \\
(0.0006)\end{array}$ \\
\hline III*Share of female & $\begin{array}{c}-0.0008 \\
(0.0006)\end{array}$ & $\begin{array}{c}0.0006 \\
(0.0008)\end{array}$ & $\begin{array}{c}-0.0005 \\
(0.0006)\end{array}$ & $\begin{array}{l}-0.0012 * \\
(0.0006)\end{array}$ & $\begin{array}{c}-0.0009 \\
(0.0007)\end{array}$ \\
\hline $\mathrm{V}-\mathrm{VI} *$ Share of female & $\begin{array}{c}0.0010 \\
(0.0007)\end{array}$ & $\begin{array}{c}0.0011 \\
(0.0008)\end{array}$ & $\begin{array}{c}0.0005 \\
(0.0008)\end{array}$ & $\begin{array}{c}-0.0004 \\
(0.0008)\end{array}$ & $\begin{array}{c}0.0003 \\
(0.0007)\end{array}$ \\
\hline VII*Share of female & $\begin{array}{c}-0.0010 \\
(0.0008)\end{array}$ & $\begin{array}{c}-0.0007 \\
(0.0010)\end{array}$ & $\begin{array}{c}-0.0009 \\
(0.0009)\end{array}$ & $\begin{array}{c}-0.0007 \\
(0.0007)\end{array}$ & $\begin{array}{c}-0.0012 * \\
(0.0007)\end{array}$ \\
\hline Share of white non-hispanic & $\begin{array}{c}0.0004 \\
(0.0005)\end{array}$ & $\begin{array}{c}-0.0000 \\
(0.0008)\end{array}$ & $\begin{array}{l}0.0007 * \\
(0.0004)\end{array}$ & $\begin{array}{c}0.0005 \\
(0.0006)\end{array}$ & $\begin{array}{c}0.0003 \\
(0.0004)\end{array}$ \\
\hline III*Share of white non-hispanic & $\begin{array}{c}0.0000 \\
(0.0006)\end{array}$ & $\begin{array}{c}0.0006 \\
(0.0008)\end{array}$ & $\begin{array}{c}-0.0002 \\
(0.0006)\end{array}$ & $\begin{array}{c}-0.0004 \\
(0.0008)\end{array}$ & $\begin{array}{c}-0.0004 \\
(0.0006)\end{array}$ \\
\hline $\mathrm{V}-\mathrm{VI} *$ Share of white non-hispanic & $\begin{array}{c}0.0005 \\
(0.0005)\end{array}$ & $\begin{array}{c}0.0011 \\
(0.0008)\end{array}$ & $\begin{array}{c}0.0001 \\
(0.0005)\end{array}$ & $\begin{array}{c}0.0006 \\
(0.0007)\end{array}$ & $\begin{array}{c}0.0009 \\
(0.0005)\end{array}$ \\
\hline VII*Share of white non-hispanic & $\begin{array}{c}0.0008 \\
(0.0007)\end{array}$ & $\begin{array}{c}0.0013 \\
(0.0012)\end{array}$ & $\begin{array}{c}0.0001 \\
(0.0007)\end{array}$ & $\begin{array}{c}-0.0001 \\
(0.0008)\end{array}$ & $\begin{array}{c}0.0006 \\
(0.0005)\end{array}$ \\
\hline Log of real value added & $\begin{array}{c}0.0048 \\
(0.0096)\end{array}$ & $\begin{array}{l}-0.0090 \\
(0.0147)\end{array}$ & $\begin{array}{c}0.0086 \\
(0.0077)\end{array}$ & $\begin{array}{c}0.0068 \\
(0.0082)\end{array}$ & $\begin{array}{c}0.0043 \\
(0.0061)\end{array}$ \\
\hline III* $\log$ of real value added & $\begin{array}{c}-0.0244 * * \\
(0.0119)\end{array}$ & $\begin{array}{c}-0.0157 \\
(0.0118)\end{array}$ & $\begin{array}{c}-0.0278 \text { *** } \\
(0.0102)\end{array}$ & $\begin{array}{c}-0.0257 * * * \\
(0.0081)\end{array}$ & $\begin{array}{c}-0.0225^{* *} \\
(0.0098)\end{array}$ \\
\hline $\mathrm{V}-\mathrm{VI} * \mathrm{Log}$ of real value added & $\begin{array}{c}-0.0084 \\
(0.0078)\end{array}$ & $\begin{array}{l}-0.0045 \\
(0.0095)\end{array}$ & $\begin{array}{l}-0.0061 \\
(0.0087)\end{array}$ & $\begin{array}{c}0.0055 \\
(0.0113)\end{array}$ & $\begin{array}{c}0.0039 \\
(0.0101)\end{array}$ \\
\hline VII*Log of real value added & $\begin{array}{c}-0.0207 * \\
(0.0109)\end{array}$ & $\begin{array}{l}-0.0120 \\
(0.0151)\end{array}$ & $\begin{array}{c}-0.0194 \\
(0.0118)\end{array}$ & $\begin{array}{c}-0.0148 \\
(0.0124)\end{array}$ & $\begin{array}{c}-0.0231 * * * \\
(0.0080)\end{array}$ \\
\hline Average age & $\begin{array}{c}0.0085^{* * *} \\
(0.0017)\end{array}$ & $\begin{array}{c}0.0105 * * * \\
(0.0021)\end{array}$ & $\begin{array}{c}0.0078 * * * \\
(0.0020)\end{array}$ & $\begin{array}{c}0.0090^{* * * *} \\
(0.0020)\end{array}$ & $\begin{array}{c}0.0069 * * * \\
(0.0013)\end{array}$ \\
\hline III*Average age & $\begin{array}{c}-0.0029 \\
(0.0030)\end{array}$ & $\begin{array}{l}-0.0037 \\
(0.0024)\end{array}$ & $\begin{array}{l}-0.0036 \\
(0.0022)\end{array}$ & $\begin{array}{c}-0.0043 * \\
(0.0023)\end{array}$ & $\begin{array}{c}-0.0052 * * * \\
(0.0019)\end{array}$ \\
\hline $\mathrm{V}-\mathrm{VI} *$ Average age & $\begin{array}{c}-0.0004 \\
(0.0027)\end{array}$ & $\begin{array}{c}-0.0004 \\
(0.0025)\end{array}$ & $\begin{array}{c}-0.0013 \\
(0.0020)\end{array}$ & $\begin{array}{c}-0.0033 \\
(0.0025)\end{array}$ & $\begin{array}{c}0.0005 \\
(0.0023)\end{array}$ \\
\hline VII*Average age & $\begin{array}{c}-0.0066 * * * \\
(0.0022)\end{array}$ & $\begin{array}{l}-0.0051^{*} \\
(0.0030)\end{array}$ & $\begin{array}{c}-0.0040 \\
(0.0026)\end{array}$ & $\begin{array}{c}-0.0061 * * * \\
(0.0020)\end{array}$ & $\begin{array}{l}-0.0034^{*} \\
(0.0017)\end{array}$ \\
\hline L. Mean of $\ln$ earnings & $\begin{array}{c}0.2866^{* * * *} \\
(0.0391)\end{array}$ & & $\begin{array}{c}0.2919 * * * \\
(0.0416)\end{array}$ & $\begin{array}{c}0.3741 * * * \\
(0.0424)\end{array}$ & $\begin{array}{c}0.4485^{* * * *} \\
(0.0456)\end{array}$ \\
\hline III*L. Mean of ln earnings & $\begin{array}{c}-0.1096^{*} \\
(0.0605)\end{array}$ & & $\begin{array}{c}0.0096 \\
(0.0414)\end{array}$ & $\begin{array}{c}0.0129 \\
(0.0425)\end{array}$ & $\begin{array}{c}0.0950 * * \\
(0.0386)\end{array}$ \\
\hline V-VI*L. Mean of ln earnings & $\begin{array}{l}-0.0059 \\
(0.0596)\end{array}$ & & $\begin{array}{c}0.0264 \\
(0.0555)\end{array}$ & $\begin{array}{l}-0.0577 \\
(0.0618)\end{array}$ & $\begin{array}{l}-0.0613 \\
(0.0671)\end{array}$ \\
\hline VII*L. Mean of ln earnings & $\begin{array}{c}0.1181 \\
(0.0833)\end{array}$ & & $\begin{array}{l}0.1340^{*} \\
(0.0729)\end{array}$ & $\begin{array}{c}0.1200 * * \\
(0.0535)\end{array}$ & $\begin{array}{c}0.0651 \\
(0.0472)\end{array}$ \\
\hline L. Median of $\ln$ earnings & & $\begin{array}{c}0.2345^{* * *} \\
(0.0456)\end{array}$ & & & \\
\hline III*L. Median of ln earnings & & $\begin{array}{l}-0.1147 \\
(0.0953)\end{array}$ & & & \\
\hline V-VI*L. Median of ln earnings & & $\begin{array}{l}-0.0827 \\
(0.0860)\end{array}$ & & & \\
\hline VII*L. Median of ln earnings & & $\begin{array}{c}0.1255 \\
(0.0871)\end{array}$ & & & \\
\hline Year-Class FE & Yes & Yes & Yes & Yes & Yes \\
\hline Observations & 5,760 & 5,760 & 5,410 & 4,721 & 5,760 \\
\hline R-squared & 0.5759 & 0.4470 & 0.6369 & 0.7101 & 0.8164 \\
\hline Number of id & 160 & 160 & 159 & 150 & 160 \\
\hline
\end{tabular}

Cluster robust standard errors at the industry level in parentheses; *** $p<0.01, * * p<0.05, * p<0.1$ 
Table A3 Stepwise regressions from baseline two-way fixed-effects models fully interacted

\begin{tabular}{|c|c|c|c|c|c|c|c|}
\hline VARIABLES & M6 & M7 & M8 & M9 & M10 & M11 & M12 \\
\hline ICT shares & $\begin{array}{c}0.0011 * * * \\
(0.0004)\end{array}$ & $\begin{array}{l}0.0007 * \\
(0.0004)\end{array}$ & $\begin{array}{c}0.0003 \\
(0.0003)\end{array}$ & $\begin{array}{c}0.0001 \\
(0.0003)\end{array}$ & $\begin{array}{c}0.0001 \\
(0.0003)\end{array}$ & $\begin{array}{c}0.0003 \\
(0.0003)\end{array}$ & $\begin{array}{c}0.0002 \\
(0.0003)\end{array}$ \\
\hline III*ICT shares & $\begin{array}{l}-0.0000 \\
(0.0007)\end{array}$ & $\begin{array}{l}-0.0000 \\
(0.0007)\end{array}$ & $\begin{array}{c}0.0001 \\
(0.0005)\end{array}$ & $\begin{array}{c}0.0001 \\
(0.0005)\end{array}$ & $\begin{array}{c}0.0001 \\
(0.0005)\end{array}$ & $\begin{array}{l}-0.0000 \\
(0.0005)\end{array}$ & $\begin{array}{c}0.0003 \\
(0.0005)\end{array}$ \\
\hline V-VI*ICT shares & $\begin{array}{c}0.0001 \\
(0.0004)\end{array}$ & $\begin{array}{l}-0.0005 \\
(0.0005)\end{array}$ & $\begin{array}{l}-0.0006 \\
(0.0005)\end{array}$ & $\begin{array}{c}-0.0004 \\
(0.0005)\end{array}$ & $\begin{array}{l}-0.0004 \\
(0.0005)\end{array}$ & $\begin{array}{l}-0.0008 \\
(0.0005)\end{array}$ & $\begin{array}{l}-0.0007 \\
(0.0006)\end{array}$ \\
\hline VII*ICT shares & $\begin{array}{l}-0.0003 \\
(0.0006)\end{array}$ & $\begin{array}{l}-0.0006 \\
(0.0007)\end{array}$ & $\begin{array}{l}-0.0004 \\
(0.0005)\end{array}$ & $\begin{array}{l}-0.0005 \\
(0.0005)\end{array}$ & $\begin{array}{l}-0.0004 \\
(0.0005)\end{array}$ & $\begin{array}{l}-0.0006 \\
(0.0004)\end{array}$ & $\begin{array}{l}-0.0004 \\
(0.0005)\end{array}$ \\
\hline Union density & & $\begin{array}{c}0.0019 * * * \\
(0.0007)\end{array}$ & $\begin{array}{c}0.0023^{* * *} * \\
(0.0006)\end{array}$ & $\begin{array}{c}0.0023 * * * * \\
(0.0007)\end{array}$ & $\begin{array}{c}0.0024 * * * \\
(0.0006)\end{array}$ & $\begin{array}{c}0.0020 * * * \\
(0.0006)\end{array}$ & $\begin{array}{c}0.0019 * * * \\
(0.0006)\end{array}$ \\
\hline III*Union density & & $\begin{array}{l}-0.0000 \\
(0.0011)\end{array}$ & $\begin{array}{c}0.0003 \\
(0.0010)\end{array}$ & $\begin{array}{c}0.0006 \\
(0.0010)\end{array}$ & $\begin{array}{c}0.0008 \\
(0.0011)\end{array}$ & $\begin{array}{c}0.0011 \\
(0.0010)\end{array}$ & $\begin{array}{c}0.0014 \\
(0.0010)\end{array}$ \\
\hline V-VI*Union density & & $\begin{array}{c}0.0026 * * \\
(0.0010)\end{array}$ & $\begin{array}{c}0.0023^{* *} * \\
(0.0010)\end{array}$ & $\begin{array}{c}0.0024 * * \\
(0.0010)\end{array}$ & $\begin{array}{c}0.0025^{* *} \\
(0.0010)\end{array}$ & $\begin{array}{c}0.0023 * * \\
(0.0010)\end{array}$ & $\begin{array}{c}0.0024 * * \\
(0.0010)\end{array}$ \\
\hline VII*Union density & & $\begin{array}{c}0.0014 \\
(0.0013)\end{array}$ & $\begin{array}{c}0.0013 \\
(0.0010)\end{array}$ & $\begin{array}{c}0.0024 * * \\
(0.0009)\end{array}$ & $\begin{array}{c}0.0025 * * * \\
(0.0009)\end{array}$ & $\begin{array}{c}0.0028 * * * \\
(0.0008)\end{array}$ & $\begin{array}{c}0.0031 * * * \\
(0.0008)\end{array}$ \\
\hline Share of high educated & & & $\begin{array}{c}0.0034^{* * * *} \\
(0.0004)\end{array}$ & $\begin{array}{c}0.0031 * * * \\
(0.0003)\end{array}$ & $\begin{array}{c}0.0031 * * * \\
(0.0003)\end{array}$ & $\begin{array}{c}0.0032 * * * \\
(0.0003)\end{array}$ & $\begin{array}{c}0.0032 * * * \\
(0.0003)\end{array}$ \\
\hline III*Share of high educated & & & $\begin{array}{c}0.0016^{* * * *} \\
(0.0005)\end{array}$ & $\begin{array}{c}0.0015^{* * *} \\
(0.0005)\end{array}$ & $\begin{array}{c}0.0014 * * * \\
(0.0005)\end{array}$ & $\begin{array}{c}0.0012 * * \\
(0.0005)\end{array}$ & $\begin{array}{c}0.0013 * * \\
(0.0005)\end{array}$ \\
\hline $\mathrm{V}-\mathrm{VI} *$ Share of high educated & & & $\begin{array}{l}-0.0008 \\
(0.0005)\end{array}$ & $\begin{array}{l}-0.0003 \\
(0.0005)\end{array}$ & $\begin{array}{l}-0.0003 \\
(0.0005)\end{array}$ & $\begin{array}{c}-0.0003 \\
(0.0005)\end{array}$ & $\begin{array}{l}-0.0003 \\
(0.0005)\end{array}$ \\
\hline VII*Share of high educated & & & $\begin{array}{c}0.0008 \\
(0.0011)\end{array}$ & $\begin{array}{c}0.0008 \\
(0.0010)\end{array}$ & $\begin{array}{c}0.0008 \\
(0.0010)\end{array}$ & $\begin{array}{c}0.0007 \\
(0.0010)\end{array}$ & $\begin{array}{c}0.0010 \\
(0.0010)\end{array}$ \\
\hline Share of female & & & & $\begin{array}{c}-0.0023 * * * \\
(0.0005)\end{array}$ & $\begin{array}{c}-0.0023 * * * \\
(0.0005)\end{array}$ & $\begin{array}{c}-0.0020 * * * \\
(0.0005)\end{array}$ & $\begin{array}{c}-0.0019^{* * *} \\
(0.0005)\end{array}$ \\
\hline III*Share of female & & & & $\begin{array}{l}-0.0001 \\
(0.0007)\end{array}$ & $\begin{array}{c}-0.0002 \\
(0.0007)\end{array}$ & $\begin{array}{l}-0.0006 \\
(0.0006)\end{array}$ & $\begin{array}{l}-0.0008 \\
(0.0006)\end{array}$ \\
\hline V-VI*Share of female & & & & $\begin{array}{c}0.0012 \\
(0.0007)\end{array}$ & $\begin{array}{c}0.0011 \\
(0.0007)\end{array}$ & $\begin{array}{c}0.0011 \\
(0.0007)\end{array}$ & $\begin{array}{c}0.0010 \\
(0.0007)\end{array}$ \\
\hline VII*Share of female & & & & $\begin{array}{l}-0.0007 \\
(0.0009)\end{array}$ & $\begin{array}{l}-0.0006 \\
(0.0009)\end{array}$ & $\begin{array}{l}-0.0010 \\
(0.0009)\end{array}$ & $\begin{array}{l}-0.0010 \\
(0.0008)\end{array}$ \\
\hline Share of white non-Hispanic & & & & & $\begin{array}{l}0.0008^{*} \\
(0.0004)\end{array}$ & $\begin{array}{c}0.0003 \\
(0.0004)\end{array}$ & $\begin{array}{c}0.0004 \\
(0.0005)\end{array}$ \\
\hline III*Share of white non-Hispanic & & & & & $\begin{array}{c}0.0001 \\
(0.0005)\end{array}$ & $\begin{array}{c}0.0001 \\
(0.0006)\end{array}$ & $\begin{array}{c}0.0000 \\
(0.0006)\end{array}$ \\
\hline V-VI*Share of white non-Hispanic & & & & & $\begin{array}{c}0.0004 \\
(0.0005)\end{array}$ & $\begin{array}{c}0.0006 \\
(0.0005)\end{array}$ & $\begin{array}{c}0.0005 \\
(0.0005)\end{array}$ \\
\hline VII*Share of white non-Hispanic & & & & & $\begin{array}{c}0.0004 \\
(0.0007)\end{array}$ & $\begin{array}{c}0.0008 \\
(0.0007)\end{array}$ & $\begin{array}{c}0.0008 \\
(0.0007)\end{array}$ \\
\hline Average age & & & & & & $\begin{array}{c}0.0086^{* * *} * \\
(0.0017)\end{array}$ & $\begin{array}{c}0.0085^{* * *} \\
(0.0017)\end{array}$ \\
\hline III*Average age & & & & & & $\begin{array}{c}-0.0028 \\
(0.0031)\end{array}$ & $\begin{array}{l}-0.0029 \\
(0.0030)\end{array}$ \\
\hline V-VI*Average age & & & & & & $\begin{array}{l}-0.0004 \\
(0.0027)\end{array}$ & $\begin{array}{l}-0.0004 \\
(0.0027)\end{array}$ \\
\hline VII*Average age & & & & & & $\begin{array}{c}-0.0066^{* * * *} \\
(0.0022)\end{array}$ & $\begin{array}{c}-0.0066^{* * * *} \\
(0.0022)\end{array}$ \\
\hline Log of real value-added & & & & & & & $\begin{array}{c}0.0048 \\
(0.0096)\end{array}$ \\
\hline III*Log of real value-added & & & & & & & $\begin{array}{c}-0.0244 * * \\
(0.0119)\end{array}$ \\
\hline V-VI*Log of real value-added & & & & & & & $\begin{array}{c}-0.0084 \\
(0.0078)\end{array}$ \\
\hline VII*Log of real value-added & & & & & & & $\begin{array}{c}-0.0207^{*} \\
(0.0109)\end{array}$ \\
\hline L. Mean of ln earnings & $\begin{array}{c}0.3935 * * * \\
(0.0508)\end{array}$ & $\begin{array}{c}0.3719 * * * \\
(0.0496)\end{array}$ & $\begin{array}{c}0.3168 * * * \\
(0.0430)\end{array}$ & $\begin{array}{c}0.2908 * * * \\
(0.0416)\end{array}$ & $\begin{array}{c}0.2956^{* * *} * \\
(0.0413)\end{array}$ & $\begin{array}{c}0.2877 * * * \\
(0.0393)\end{array}$ & $\begin{array}{c}0.2866 * * * \\
(0.0391)\end{array}$ \\
\hline III*L. Mean of ln earnings & $\begin{array}{l}-0.1317^{*} \\
(0.0723)\end{array}$ & $\begin{array}{l}-0.1207 \\
(0.0730)\end{array}$ & $\begin{array}{l}-0.1180^{*} \\
(0.0680)\end{array}$ & $\begin{array}{c}-0.1019^{*} \\
(0.0595)\end{array}$ & $\begin{array}{c}-0.1138^{*} \\
(0.0593)\end{array}$ & $\begin{array}{l}-0.1095^{*} \\
(0.0611)\end{array}$ & $\begin{array}{c}-0.1096^{*} \\
(0.0605)\end{array}$ \\
\hline V-VI*L. Mean of ln earnings & $\begin{array}{c}0.0136 \\
(0.0685)\end{array}$ & $\begin{array}{c}-0.0414 \\
(0.0694)\end{array}$ & $\begin{array}{l}-0.0223 \\
(0.0582)\end{array}$ & $\begin{array}{l}-0.0011 \\
(0.0588)\end{array}$ & $\begin{array}{l}-0.0131 \\
(0.0612)\end{array}$ & $\begin{array}{l}-0.0068 \\
(0.0606)\end{array}$ & $\begin{array}{l}-0.0059 \\
(0.0596)\end{array}$ \\
\hline VII*L. Mean of ln earnings & $\begin{array}{c}0.1428 \\
(0.0969)\end{array}$ & $\begin{array}{c}0.1116 \\
(0.1041)\end{array}$ & $\begin{array}{c}0.1374 \\
(0.0979)\end{array}$ & $\begin{array}{c}0.1201 \\
(0.0875)\end{array}$ & $\begin{array}{c}0.1101 \\
(0.0866)\end{array}$ & $\begin{array}{c}0.1211 \\
(0.0877)\end{array}$ & $\begin{array}{c}0.1181 \\
(0.0833)\end{array}$ \\
\hline Year fixed-effects & Yes & Yes & Yes & Yes & Yes & Yes & Yes \\
\hline Observations & 5,760 & 5,760 & 5,760 & 5,760 & 5,760 & 5,760 & 5,760 \\
\hline R-squared & 0.4728 & 0.4884 & 0.5369 & 0.5583 & 0.5624 & 0.5741 & 0.5759 \\
\hline Number of id & 160 & 160 & 160 & 160 & 160 & 160 & 160 \\
\hline
\end{tabular}


Table A4 ECM models fully interacted by EGP classes (M13), robustness checks for top-codes (M14) and cell-size (M15-M16)

\begin{tabular}{|c|c|c|c|c|c|}
\hline VARIABLES & $\begin{array}{c}\text { M13 } \\
\text { Main model interacted } \\
\end{array}$ & $\begin{array}{c}\text { M14 } \\
\text { Median earnings } \\
\end{array}$ & $\begin{array}{l}\mathrm{M} 15 \\
\mathrm{~N}>49 \\
\end{array}$ & $\begin{array}{l}\text { M16 } \\
\mathrm{N}>99 \\
\end{array}$ & $\begin{array}{c}\text { M17 } \\
\text { Weighted by average cell size } \\
\end{array}$ \\
\hline L. ICT investments & $\begin{array}{c}0.0001 \\
(0.0003)\end{array}$ & $\begin{array}{c}0.0003 \\
(0.0004)\end{array}$ & $\begin{array}{c}0.0001 \\
(0.0003)\end{array}$ & $\begin{array}{l}-0.0001 \\
(0.0003)\end{array}$ & $\begin{array}{c}0.0001 \\
(0.0002)\end{array}$ \\
\hline$I I I * L . I C T$ investments & $\begin{array}{c}0.0003 \\
(0.0005)\end{array}$ & $\begin{array}{c}0.0003 \\
(0.0007)\end{array}$ & $\begin{array}{c}0.0002 \\
(0.0004)\end{array}$ & $\begin{array}{c}0.0001 \\
(0.0003)\end{array}$ & $\begin{array}{l}-0.0002 \\
(0.0003)\end{array}$ \\
\hline$V$-VI*L. ICT investments & $\begin{array}{l}-0.0006 \\
(0.0006)\end{array}$ & $\begin{array}{l}-0.0007 \\
(0.0006)\end{array}$ & $\begin{array}{l}-0.0005 \\
(0.0005)\end{array}$ & $\begin{array}{l}-0.0004 \\
(0.0005)\end{array}$ & $\begin{array}{l}-0.0004 \\
(0.0005)\end{array}$ \\
\hline$V I I * L . I C T$ investments & $\begin{array}{l}-0.0003 \\
(0.0005)\end{array}$ & $\begin{array}{l}-0.0005 \\
(0.0006)\end{array}$ & $\begin{array}{l}-0.0006 \\
(0.0005)\end{array}$ & $\begin{array}{l}-0.0006 \\
(0.0004)\end{array}$ & $\begin{array}{l}-0.0001 \\
(0.0004)\end{array}$ \\
\hline$\triangle I C T$ investments & $\begin{array}{c}0.0017 * * \\
(0.0008)\end{array}$ & $\begin{array}{c}0.0025^{* *} \\
(0.0011)\end{array}$ & $\begin{array}{c}0.0014 * * \\
(0.0006)\end{array}$ & $\begin{array}{c}0.0012 * * \\
(0.0006)\end{array}$ & $\begin{array}{c}0.0006 \\
(0.0005)\end{array}$ \\
\hline$I I I^{*} \Delta$ ICT investments & $\begin{array}{c}0.0006 \\
(0.0009)\end{array}$ & $\begin{array}{l}-0.0008 \\
(0.0013)\end{array}$ & $\begin{array}{c}0.0004 \\
(0.0007)\end{array}$ & $\begin{array}{l}-0.0004 \\
(0.0008)\end{array}$ & $\begin{array}{c}0.0003 \\
(0.0005)\end{array}$ \\
\hline$V-V I * \Delta I C T$ investments & $\begin{array}{l}-0.0010 \\
(0.0013)\end{array}$ & $\begin{array}{l}-0.0012 \\
(0.0020)\end{array}$ & $\begin{array}{l}-0.0003 \\
(0.0015)\end{array}$ & $\begin{array}{c}-0.0007 \\
(0.0016)\end{array}$ & $\begin{array}{c}0.0005 \\
(0.0010)\end{array}$ \\
\hline$V I I * \Delta I C T$ investments & $\begin{array}{l}-0.0011 \\
(0.0015)\end{array}$ & $\begin{array}{l}-0.0011 \\
(0.0021)\end{array}$ & $\begin{array}{c}0.0004 \\
(0.0012)\end{array}$ & $\begin{array}{c}-0.0012 \\
(0.0008)\end{array}$ & $\begin{array}{l}-0.0002 \\
(0.0008)\end{array}$ \\
\hline L.Union density & $\begin{array}{c}0.0018^{* *} \\
(0.0007)\end{array}$ & $\begin{array}{c}0.0022 * * * \\
(0.0008)\end{array}$ & $\begin{array}{c}0.0018 * * * \\
(0.0006)\end{array}$ & $\begin{array}{c}0.0020^{* * *} * \\
(0.0004)\end{array}$ & $\begin{array}{c}0.0015 * * * \\
(0.0004)\end{array}$ \\
\hline III*L.Union density & $\begin{array}{c}0.0011 \\
(0.0012)\end{array}$ & $\begin{array}{c}0.0016 \\
(0.0014)\end{array}$ & $\begin{array}{c}0.0012 \\
(0.0011)\end{array}$ & $\begin{array}{l}0.0014^{*} \\
(0.0008)\end{array}$ & $\begin{array}{c}0.0007 \\
(0.0007)\end{array}$ \\
\hline$V-V I^{*}$ L.Union density & $\begin{array}{c}0.0024 * * \\
(0.0010)\end{array}$ & $\begin{array}{c}0.0029 * * \\
(0.0011)\end{array}$ & $\begin{array}{c}0.0020 * * \\
(0.0009)\end{array}$ & $\begin{array}{c}0.0023^{* * *} * \\
(0.0008)\end{array}$ & $\begin{array}{c}0.0026 * * * \\
(0.0008)\end{array}$ \\
\hline VII* L.Union density & $\begin{array}{c}0.0030 * * * \\
(0.0009)\end{array}$ & $\begin{array}{c}0.0046 * * * \\
(0.0010)\end{array}$ & $\begin{array}{c}0.0022 * * \\
(0.0009)\end{array}$ & $\begin{array}{c}0.0019^{* *} \\
(0.0008)\end{array}$ & $\begin{array}{c}0.0025 * * * \\
(0.0006)\end{array}$ \\
\hline$\Delta$ Union density & $\begin{array}{c}0.0007 \\
(0.0010)\end{array}$ & $\begin{array}{c}0.0012 \\
(0.0019)\end{array}$ & $\begin{array}{c}0.0003 \\
(0.0010)\end{array}$ & $\begin{array}{c}0.0011 \\
(0.0014)\end{array}$ & $\begin{array}{l}0.0017^{*} \\
(0.0009)\end{array}$ \\
\hline$I I I * \Delta$ Union density & $\begin{array}{c}0.0030^{* *} * \\
(0.0015)\end{array}$ & $\begin{array}{c}0.0049 * * \\
(0.0021)\end{array}$ & $\begin{array}{l}0.0021^{*} \\
(0.0011)\end{array}$ & $\begin{array}{c}0.0026 \\
(0.0019)\end{array}$ & $\begin{array}{c}0.0007 \\
(0.0014)\end{array}$ \\
\hline$V-V I^{*} \Delta$ Union density & $\begin{array}{l}0.0031^{*} \\
(0.0016)\end{array}$ & $\begin{array}{c}0.0034 \\
(0.0023)\end{array}$ & $\begin{array}{l}0.0027^{*} \\
(0.0015)\end{array}$ & $\begin{array}{c}0.0012 \\
(0.0016)\end{array}$ & $\begin{array}{c}0.0016 \\
(0.0012)\end{array}$ \\
\hline$V I I * \Delta$ Union density & $\begin{array}{c}0.0042^{* * *} * \\
(0.0015)\end{array}$ & $\begin{array}{l}0.0041 * \\
(0.0023)\end{array}$ & $\begin{array}{c}0.0043^{* * * *} \\
(0.0014)\end{array}$ & $\begin{array}{c}0.0038^{* *} * \\
(0.0018)\end{array}$ & $\begin{array}{c}0.0031 * * * \\
(0.0011)\end{array}$ \\
\hline L.Share of high-edu & $\begin{array}{l}0.0026 * * * \\
(0.0005)\end{array}$ & $\begin{array}{c}0.0031 * * * \\
(0.0006)\end{array}$ & $\begin{array}{c}0.0023 * * * \\
(0.0004)\end{array}$ & $\begin{array}{c}0.0027 * * * \\
(0.0005)\end{array}$ & $\begin{array}{c}0.0020 * * * \\
(0.0004)\end{array}$ \\
\hline$I I I *$ L.Share of high-edu & $\begin{array}{l}0.0018^{*} \\
(0.0011)\end{array}$ & $\begin{array}{c}0.0020 * * \\
(0.0009)\end{array}$ & $\begin{array}{c}0.0004 \\
(0.0007)\end{array}$ & $\begin{array}{l}-0.0002 \\
(0.0008)\end{array}$ & $\begin{array}{l}-0.0004 \\
(0.0006)\end{array}$ \\
\hline$V-V I *$ L.Share of high-edu & $\begin{array}{c}0.0001 \\
(0.0006)\end{array}$ & $\begin{array}{l}-0.0003 \\
(0.0008)\end{array}$ & $\begin{array}{l}-0.0003 \\
(0.0006)\end{array}$ & $\begin{array}{l}-0.0002 \\
(0.0008)\end{array}$ & $\begin{array}{c}0.0001 \\
(0.0005)\end{array}$ \\
\hline$V I I * L$.Share of high-edu & $\begin{array}{c}0.0003 \\
(0.0010)\end{array}$ & $\begin{array}{c}-0.0002 \\
(0.0013)\end{array}$ & $\begin{array}{c}-0.0003 \\
(0.0013)\end{array}$ & $\begin{array}{c}-0.0032 * * \\
(0.0015)\end{array}$ & $\begin{array}{l}-0.0013 \\
(0.0010)\end{array}$ \\
\hline$\Delta$ Share of high-edu & $\begin{array}{c}0.0035^{* * *} \\
(0.0004)\end{array}$ & $\begin{array}{c}0.0035 * * * \\
(0.0005)\end{array}$ & $\begin{array}{c}0.0034 * * * \\
(0.0003)\end{array}$ & $\begin{array}{c}0.0036^{* * * *} \\
(0.0004)\end{array}$ & $\begin{array}{c}0.0036 * * * \\
(0.0003)\end{array}$ \\
\hline$I I I^{*} \Delta$ Share of high-edu & $\begin{array}{l}0.0010^{* * *} \\
(0.0004)\end{array}$ & $\begin{array}{c}0.0008 \\
(0.0009)\end{array}$ & $\begin{array}{c}0.0012 * * \\
(0.0005)\end{array}$ & $\begin{array}{l}0.0006 \\
(0.0007)\end{array}$ & $\begin{array}{c}0.0004 \\
(0.0005)\end{array}$ \\
\hline$V-V I^{*} \Delta$ Share of high-edu & $\begin{array}{l}-0.0004 \\
(0.0007)\end{array}$ & $\begin{array}{l}-0.0013 \\
(0.0009)\end{array}$ & $\begin{array}{c}0.0001 \\
(0.0004)\end{array}$ & $\begin{array}{c}0.0003 \\
(0.0007)\end{array}$ & $\begin{array}{l}-0.0005 \\
(0.0007)\end{array}$ \\
\hline$V I I * \Delta$ Share of high-edu & $\begin{array}{c}0.0008 \\
(0.0010)\end{array}$ & $\begin{array}{c}0.0000 \\
(0.0013)\end{array}$ & $\begin{array}{c}0.0007 \\
(0.0012)\end{array}$ & $\begin{array}{l}-0.0019^{*} \\
(0.0010)\end{array}$ & $\begin{array}{l}-0.0007 \\
(0.0009)\end{array}$ \\
\hline L.Share of female & $\begin{array}{c}-0.0013 * * \\
(0.0006)\end{array}$ & $\begin{array}{c}-0.0021 * * * \\
(0.0006)\end{array}$ & $\begin{array}{c}-0.0013 * * \\
(0.0006)\end{array}$ & $\begin{array}{c}-0.0011 * * \\
(0.0005)\end{array}$ & $\begin{array}{l}-0.0010 \\
(0.0006)\end{array}$ \\
\hline III*L.Share of female & $\begin{array}{l}-0.0009 \\
(0.0008)\end{array}$ & $\begin{array}{l}-0.0001 \\
(0.0011)\end{array}$ & $\begin{array}{l}-0.0009 \\
(0.0007)\end{array}$ & $\begin{array}{l}-0.0010 \\
(0.0006)\end{array}$ & $\begin{array}{l}-0.0006 \\
(0.0006)\end{array}$ \\
\hline$V$-VI*L.Share of female & $\begin{array}{c}0.0011 \\
(0.0009)\end{array}$ & $\begin{array}{c}0.0015 \\
(0.0009)\end{array}$ & $\begin{array}{c}0.0002 \\
(0.0010)\end{array}$ & $\begin{array}{l}-0.0003 \\
(0.0011)\end{array}$ & $\begin{array}{c}0.0003 \\
(0.0008)\end{array}$ \\
\hline$V I I * L$.Share of female & $\begin{array}{c}-0.0017 \\
(0.0011)\end{array}$ & $\begin{array}{c}-0.0018 \\
(0.0014)\end{array}$ & $\begin{array}{l}-0.0009 \\
(0.0011)\end{array}$ & $\begin{array}{l}-0.0005 \\
(0.0008)\end{array}$ & $\begin{array}{c}-0.0014 * * \\
(0.0007)\end{array}$ \\
\hline$\Delta$ Share of female & $\begin{array}{c}-0.0020 * * * \\
(0.0005)\end{array}$ & $\begin{array}{c}-0.0028 * * * \\
(0.0006)\end{array}$ & $\begin{array}{c}-0.0019 * * * \\
(0.0005)\end{array}$ & $\begin{array}{c}-0.0015 * * * \\
(0.0005)\end{array}$ & $\begin{array}{c}-0.0019 * * * \\
(0.0005)\end{array}$ \\
\hline$I I I^{*} \Delta$ Share of female & $\begin{array}{l}-0.0008 \\
(0.0007)\end{array}$ & $\begin{array}{c}0.0007 \\
(0.0008)\end{array}$ & $\begin{array}{l}-0.0006 \\
(0.0006)\end{array}$ & $\begin{array}{c}-0.0013 * \\
(0.0007)\end{array}$ & $\begin{array}{l}-0.0010 \\
(0.0006)\end{array}$ \\
\hline$V-V I * \Delta$ Share of female & $\begin{array}{c}0.0010 \\
(0.0008)\end{array}$ & $\begin{array}{c}0.0011 \\
(0.0009)\end{array}$ & $\begin{array}{c}0.0003 \\
(0.0008)\end{array}$ & $\begin{array}{l}-0.0011 \\
(0.0009)\end{array}$ & $\begin{array}{c}0.0001 \\
(0.0006)\end{array}$ \\
\hline$V I I * \Delta$ Share of female & $\begin{array}{c}-0.0007 \\
(0.0008)\end{array}$ & $\begin{array}{c}-0.0003 \\
(0.0009)\end{array}$ & $\begin{array}{c}-0.0010 \\
(0.0009)\end{array}$ & $\begin{array}{l}-0.0011 \\
(0.0008)\end{array}$ & $\begin{array}{l}-0.0010^{*} \\
(0.0006)\end{array}$ \\
\hline L.Average age & $\begin{array}{c}0.0060^{* * * *} \\
(0.0015)\end{array}$ & $\begin{array}{c}0.0092 * * * \\
(0.0020)\end{array}$ & $\begin{array}{c}0.0056^{* * *} \\
(0.0015)\end{array}$ & $\begin{array}{c}0.0049 * * * \\
(0.0018)\end{array}$ & $\begin{array}{c}0.0047 * * * \\
(0.0012)\end{array}$ \\
\hline$I I{ }^{*}$ L.Average age & $\begin{array}{l}-0.0003 \\
(0.0035)\end{array}$ & $\begin{array}{c}0.0009 \\
(0.0035)\end{array}$ & $\begin{array}{l}-0.0030 \\
(0.0022)\end{array}$ & $\begin{array}{l}-0.0023 \\
(0.0026)\end{array}$ & $\begin{array}{c}-0.0048^{* *} \\
(0.0018)\end{array}$ \\
\hline$V$-VI*L.Average age & $\begin{array}{l}-0.0001 \\
(0.0037)\end{array}$ & $\begin{array}{l}-0.0022 \\
(0.0032)\end{array}$ & $\begin{array}{l}-0.0025 \\
(0.0016)\end{array}$ & $\begin{array}{l}-0.0024 \\
(0.0024)\end{array}$ & $\begin{array}{l}-0.0009 \\
(0.0025)\end{array}$ \\
\hline VII $*$ L.Average age & $\begin{array}{c}-0.0087 * * * \\
(0.0022)\end{array}$ & $\begin{array}{c}-0.0091 * * * \\
(0.0024)\end{array}$ & $\begin{array}{c}-0.0048^{* *} \\
(0.0019)\end{array}$ & $\begin{array}{c}-0.0046^{* * *} \\
(0.0021)\end{array}$ & $\begin{array}{l}-0.0034^{*} \\
(0.0018)\end{array}$ \\
\hline$\Delta$ Average age & $\begin{array}{c}0.0111 * * * \\
(0.0017)\end{array}$ & $\begin{array}{c}0.0126 * * * \\
(0.0024)\end{array}$ & $\begin{array}{c}0.0104 * * * \\
(0.0022)\end{array}$ & $\begin{array}{c}0.0139 * * * \\
(0.0019)\end{array}$ & $\begin{array}{c}0.0124 * * * * \\
(0.0013)\end{array}$ \\
\hline$I I I^{*} \Delta$ Average age & $\begin{array}{l}-0.0052 \\
(0.0032)\end{array}$ & $\begin{array}{c}-0.0068 * * \\
(0.0026)\end{array}$ & $\begin{array}{l}-0.0039 \\
(0.0026)\end{array}$ & $\begin{array}{c}-0.0070 * * * \\
(0.0023)\end{array}$ & $\begin{array}{c}-0.0058 * * * * \\
(0.0017)\end{array}$ \\
\hline
\end{tabular}




\begin{tabular}{|c|c|c|c|c|c|}
\hline $\begin{array}{l}V-V I^{*} \Delta \text { Average age } \\
V I I^{*} \Delta \text { Average age }\end{array}$ & $\begin{array}{c}-0.0011 \\
(0.0023) \\
-0.0077 * * * \\
(0.0027)\end{array}$ & $\begin{array}{l}-0.0001 \\
(0.0028) \\
-0.0052 \\
(0.0035)\end{array}$ & $\begin{array}{l}-0.0012 \\
(0.0023) \\
-0.0045 \\
(0.0032)\end{array}$ & $\begin{array}{c}-0.0055^{* *} \\
(0.0025) \\
-0.0091 * * * \\
(0.0025)\end{array}$ & $\begin{array}{c}-0.0016 \\
(0.0020) \\
-0.0069 * * * \\
(0.0020)\end{array}$ \\
\hline L.Share of white & $\begin{array}{c}0.0002 \\
(0.0006)\end{array}$ & $\begin{array}{l}-0.0005 \\
(0.0011)\end{array}$ & $\begin{array}{c}0.0005 \\
(0.0006)\end{array}$ & $\begin{array}{c}0.0001 \\
(0.0009)\end{array}$ & $\begin{array}{l}-0.0003 \\
(0.0005)\end{array}$ \\
\hline$I I I^{*}$ L.Share of white & $\begin{array}{c}-0.0006 \\
(0.0008)\end{array}$ & $\begin{array}{c}-0.0003 \\
(0.0011)\end{array}$ & $\begin{array}{c}-0.0005 \\
(0.0009)\end{array}$ & $\begin{array}{c}-0.0005 \\
(0.0011)\end{array}$ & $\begin{array}{l}-0.0003 \\
(0.0008)\end{array}$ \\
\hline$V-V I * L$.Share of white & $\begin{array}{c}0.0004 \\
(0.0008)\end{array}$ & $\begin{array}{c}0.0014 \\
(0.0010)\end{array}$ & $\begin{array}{c}0.0001 \\
(0.0007)\end{array}$ & $\begin{array}{c}0.0010 \\
(0.0011)\end{array}$ & $\begin{array}{l}0.0014 * * \\
(0.0007)\end{array}$ \\
\hline$V I I^{*} L$.Share of white & $\begin{array}{c}0.0003 \\
(0.0008)\end{array}$ & $\begin{array}{c}0.0010 \\
(0.0012)\end{array}$ & $\begin{array}{c}-0.0002 \\
(0.0008)\end{array}$ & $\begin{array}{l}-0.0000 \\
(0.0010)\end{array}$ & $\begin{array}{c}0.0010 \\
(0.0006)\end{array}$ \\
\hline$\Delta$ Share of white & $\begin{array}{c}0.0004 \\
(0.0004)\end{array}$ & $\begin{array}{c}0.0002 \\
(0.0008)\end{array}$ & $\begin{array}{c}0.0008 * * \\
(0.0004)\end{array}$ & $\begin{array}{c}0.0009 \\
(0.0005)\end{array}$ & $\begin{array}{c}0.0003 \\
(0.0003)\end{array}$ \\
\hline$I I{ }^{*} \Delta$ Share of white & $\begin{array}{c}0.0003 \\
(0.0006)\end{array}$ & $\begin{array}{c}0.0007 \\
(0.0009)\end{array}$ & $\begin{array}{c}0.0003 \\
(0.0005)\end{array}$ & $\begin{array}{c}-0.0003 \\
(0.0008)\end{array}$ & $\begin{array}{c}0.0007 \\
(0.0005)\end{array}$ \\
\hline$V-V I^{*} \Delta$ Share of white & $\begin{array}{c}0.0008 \\
(0.0005)\end{array}$ & $\begin{array}{c}0.0013 \\
(0.0009)\end{array}$ & $\begin{array}{c}0.0005 \\
(0.0006)\end{array}$ & $\begin{array}{c}0.0004 \\
(0.0007)\end{array}$ & $\begin{array}{c}0.0012 * * \\
(0.0005)\end{array}$ \\
\hline$V I I * \Delta$ Share of white & $\begin{array}{c}0.0012 \\
(0.0008)\end{array}$ & $\begin{array}{c}0.0016 \\
(0.0012)\end{array}$ & $\begin{array}{c}0.0004 \\
(0.0007)\end{array}$ & $\begin{array}{l}-0.0002 \\
(0.0008)\end{array}$ & $\begin{array}{c}0.0011 * * \\
(0.0005)\end{array}$ \\
\hline L.Log of real value added & $\begin{array}{c}0.0084 \\
(0.0087)\end{array}$ & $\begin{array}{l}-0.0071 \\
(0.0145)\end{array}$ & $\begin{array}{l}0.0122^{*} \\
(0.0073)\end{array}$ & $\begin{array}{c}0.0069 \\
(0.0080)\end{array}$ & $\begin{array}{c}0.0046 \\
(0.0048)\end{array}$ \\
\hline III*L.Log of real value added & $\begin{array}{l}-0.0240^{*} \\
(0.0125)\end{array}$ & $\begin{array}{c}-0.0176 \\
(0.0134)\end{array}$ & $\begin{array}{c}-0.0255^{* *} \\
(0.0114)\end{array}$ & $\begin{array}{l}-0.0171^{*} \\
(0.0092)\end{array}$ & $\begin{array}{c}-0.0145 \\
(0.0095)\end{array}$ \\
\hline$V-V I * L . L o g$ of real value added & $\begin{array}{l}-0.0095 \\
(0.0079)\end{array}$ & $\begin{array}{l}-0.0039 \\
(0.0090)\end{array}$ & $\begin{array}{l}-0.0069 \\
(0.0079)\end{array}$ & $\begin{array}{c}0.0063 \\
(0.0113)\end{array}$ & $\begin{array}{c}0.0041 \\
(0.0081)\end{array}$ \\
\hline VII*L.Log of real value added & $\begin{array}{l}-0.0189 \\
(0.0118)\end{array}$ & $\begin{array}{l}-0.0096 \\
(0.0173)\end{array}$ & $\begin{array}{l}-0.0208^{*} \\
(0.0104)\end{array}$ & $\begin{array}{l}-0.0129 \\
(0.0114)\end{array}$ & $\begin{array}{c}-0.0195 * * * \\
(0.0062)\end{array}$ \\
\hline$\Delta$ Log of real value added & $\begin{array}{c}0.0051 \\
(0.0233)\end{array}$ & $\begin{array}{l}-0.0131 \\
(0.0324)\end{array}$ & $\begin{array}{c}0.0022 \\
(0.0239)\end{array}$ & $\begin{array}{c}0.0174 \\
(0.0207)\end{array}$ & $\begin{array}{c}0.0003 \\
(0.0120)\end{array}$ \\
\hline$I I I^{*} \Delta$ Log of real value added & $\begin{array}{l}-0.0450^{* * *} \\
(0.0195)\end{array}$ & $\begin{array}{c}0.0010 \\
(0.0290)\end{array}$ & $\begin{array}{l}-0.0106 \\
(0.0331)\end{array}$ & $\begin{array}{l}-0.0550 \\
(0.0345)\end{array}$ & $\begin{array}{l}-0.0101 \\
(0.0217)\end{array}$ \\
\hline$V-V I^{*} \Delta$ Log of real value added & $\begin{array}{c}0.0009 \\
(0.0251)\end{array}$ & $\begin{array}{c}0.0210 \\
(0.0369)\end{array}$ & $\begin{array}{l}-0.0034 \\
(0.0247)\end{array}$ & $\begin{array}{l}-0.0023 \\
(0.0216)\end{array}$ & $\begin{array}{c}0.0206 \\
(0.0202)\end{array}$ \\
\hline$V I I^{*} \Delta$ Log of real value added & $\begin{array}{l}-0.0406 \\
(0.0362)\end{array}$ & $\begin{array}{c}0.0051 \\
(0.0445)\end{array}$ & $\begin{array}{l}-0.0389 \\
(0.0367)\end{array}$ & $\begin{array}{l}-0.0528 \\
(0.0393)\end{array}$ & $\begin{array}{l}-0.0132 \\
(0.0206)\end{array}$ \\
\hline L.Mean log earnings & $\begin{array}{c}-0.6658 * * * \\
(0.0405)\end{array}$ & & $\begin{array}{c}-0.6590 * * * \\
(0.0445)\end{array}$ & $\begin{array}{c}-0.5789 * * * \\
(0.0498)\end{array}$ & $\begin{array}{c}-0.4906 * * * \\
(0.0493)\end{array}$ \\
\hline III*L.Mean log earnings & $\begin{array}{l}-0.1452 \\
(0.0871)\end{array}$ & & $\begin{array}{c}0.0290 \\
(0.0450)\end{array}$ & $\begin{array}{c}0.0310 \\
(0.0474)\end{array}$ & $\begin{array}{c}0.1025^{* *} \\
(0.0433)\end{array}$ \\
\hline$V$-VI*L.Mean log earnings & $\begin{array}{l}-0.0241 \\
(0.0699)\end{array}$ & & $\begin{array}{c}0.0268 \\
(0.0586)\end{array}$ & $\begin{array}{l}-0.0720 \\
(0.0621)\end{array}$ & $\begin{array}{l}-0.0827 \\
(0.0739)\end{array}$ \\
\hline VII*L.Mean log earnings & $\begin{array}{c}0.0976 \\
(0.0877)\end{array}$ & & $\begin{array}{c}0.1257 \\
(0.0760)\end{array}$ & $\begin{array}{l}0.1021^{*} \\
(0.0604)\end{array}$ & $\begin{array}{c}0.0417 \\
(0.0495)\end{array}$ \\
\hline L.Median log earnings & & $\begin{array}{c}-0.7377 * * * \\
(0.0411)\end{array}$ & & & \\
\hline$I I I^{*}$ L.Median log earnings & & $\begin{array}{l}-0.1828^{*} \\
(0.1052)\end{array}$ & & & \\
\hline$V-V I^{*}$ L.Median log earnings & & $\begin{array}{l}-0.0720 \\
(0.0869)\end{array}$ & & & \\
\hline$V I I *$ L.Median log earnings & & $\begin{array}{c}0.1046 \\
(0.0898)\end{array}$ & & & \\
\hline Year-class fixed effects & Yes & Yes & Yes & Yes & Yes \\
\hline Observations & 5,600 & 5,600 & 5,253 & 4,580 & 5,600 \\
\hline$R$-squared & 0.4919 & 0.4844 & 0.4781 & 0.4692 & 0.4565 \\
\hline Number of id & 160 & 160 & 159 & 149 & 160 \\
\hline
\end{tabular}


Table A5 Stepwise regression of fully interacted ECM

\begin{tabular}{|c|c|c|c|c|c|c|c|}
\hline VARIABLES & M18 & M19 & M20 & M21 & M22 & M23 & M24 \\
\hline L. ICT investments & $\begin{array}{c}0.0010^{* *} \\
(0.0004)\end{array}$ & $\begin{array}{c}0.0006 \\
(0.0004)\end{array}$ & $\begin{array}{c}0.0002 \\
(0.0003)\end{array}$ & $\begin{array}{c}0.0001 \\
(0.0003)\end{array}$ & $\begin{array}{c}0.0002 \\
(0.0003)\end{array}$ & $\begin{array}{c}0.0002 \\
(0.0003)\end{array}$ & $\begin{array}{c}0.0001 \\
(0.0003)\end{array}$ \\
\hline III*L. ICT investments & 0.0001 & 0.0001 & 0.0001 & 0.0001 & 0.0001 & 0.0001 & 0.0003 \\
\hline V-VI*L. ICT investments & $\begin{array}{c}(0.0008) \\
0.0001 \\
(0.0005)\end{array}$ & $\begin{array}{c}(0.0008) \\
-0.0004 \\
(0.0006)\end{array}$ & $\begin{array}{c}(0.0006) \\
-0.0006 \\
(0.0005)\end{array}$ & $\begin{array}{l}(0.0005) \\
-0.0005 \\
(0.0005)\end{array}$ & $\begin{array}{c}(0.0005) \\
-0.0007 \\
(0.0005)\end{array}$ & $\begin{array}{c}(0.0005) \\
-0.0007 \\
(0.0005)\end{array}$ & $\begin{array}{c}(0.0005) \\
-0.0006 \\
(0.0006)\end{array}$ \\
\hline VII*L. ICT investments & $\begin{array}{l}-0.0002 \\
(0.0007)\end{array}$ & $\begin{array}{l}-0.0005 \\
(0.0007)\end{array}$ & $\begin{array}{c}-0.0004 \\
(0.0005)\end{array}$ & $\begin{array}{l}-0.0005 \\
(0.0005)\end{array}$ & $\begin{array}{c}-0.0006 \\
(0.0004)\end{array}$ & $\begin{array}{c}-0.0005 \\
(0.0004)\end{array}$ & $\begin{array}{l}-0.0003 \\
(0.0005)\end{array}$ \\
\hline$\Delta \mathrm{ICT}$ investments & $\begin{array}{c}0.0020 * * \\
(0.0008)\end{array}$ & $\begin{array}{l}0.0017 * \\
(0.0009)\end{array}$ & $\begin{array}{c}0.0018^{* *} \\
(0.0008)\end{array}$ & $\begin{array}{l}0.0014^{*} \\
(0.0008)\end{array}$ & $\begin{array}{c}0.0018^{* *} * \\
(0.0007)\end{array}$ & $\begin{array}{c}0.0018 * * \\
(0.0007)\end{array}$ & $\begin{array}{c}0.0017 * * \\
(0.0008)\end{array}$ \\
\hline III* $\Delta$ ICT investments & $\begin{array}{c}0.0004 \\
(0.0009)\end{array}$ & $\begin{array}{c}0.0004 \\
(0.0009)\end{array}$ & $\begin{array}{c}0.0003 \\
(0.0009)\end{array}$ & $\begin{array}{c}0.0008 \\
(0.0009)\end{array}$ & $\begin{array}{c}0.0004 \\
(0.0009)\end{array}$ & $\begin{array}{c}0.0003 \\
(0.0009)\end{array}$ & $\begin{array}{c}0.0006 \\
(0.0009)\end{array}$ \\
\hline $\mathrm{V}-\mathrm{VI}^{*} \Delta \mathrm{ICT}$ investments & $\begin{array}{l}-0.0005 \\
(0.0018)\end{array}$ & $\begin{array}{l}-0.0010 \\
(0.0018)\end{array}$ & $\begin{array}{l}-0.0015 \\
(0.0017)\end{array}$ & $\begin{array}{l}-0.0010 \\
(0.0016)\end{array}$ & $\begin{array}{l}-0.0010 \\
(0.0013)\end{array}$ & $\begin{array}{c}-0.0010 \\
(0.0013)\end{array}$ & $\begin{array}{l}-0.0010 \\
(0.0013)\end{array}$ \\
\hline VII* $\Delta \mathrm{ICT}$ investments & $\begin{array}{l}-0.0010 \\
(0.0017)\end{array}$ & $\begin{array}{l}-0.0013 \\
(0.0016)\end{array}$ & $\begin{array}{l}-0.0011 \\
(0.0016)\end{array}$ & $\begin{array}{l}-0.0011 \\
(0.0016)\end{array}$ & $\begin{array}{c}-0.0014 \\
(0.0015)\end{array}$ & $\begin{array}{c}-0.0014 \\
(0.0015)\end{array}$ & $\begin{array}{l}-0.0011 \\
(0.0015)\end{array}$ \\
\hline L.Union density & & $\begin{array}{c}0.0020 * * \\
(0.0008)\end{array}$ & $\begin{array}{c}0.0022 * * * \\
(0.0007)\end{array}$ & $\begin{array}{c}0.0022 * * * \\
(0.0007)\end{array}$ & $\begin{array}{c}0.0019 * * \\
(0.0007)\end{array}$ & $\begin{array}{c}0.0018^{* * *} \\
(0.0007)\end{array}$ & $\begin{array}{c}0.0018^{* *} * \\
(0.0007)\end{array}$ \\
\hline III*L.Union density & & $\begin{array}{l}-0.0002 \\
(0.0013)\end{array}$ & $\begin{array}{c}0.0003 \\
(0.0013)\end{array}$ & $\begin{array}{c}0.0004 \\
(0.0012)\end{array}$ & $\begin{array}{c}0.0008 \\
(0.0012)\end{array}$ & $\begin{array}{c}0.0007 \\
(0.0012)\end{array}$ & $\begin{array}{c}0.0011 \\
(0.0012)\end{array}$ \\
\hline V-VI*L.Union density & & $\begin{array}{c}0.0026^{* *} \\
(0.0011)\end{array}$ & $\begin{array}{c}0.0024 * * \\
(0.0010)\end{array}$ & $\begin{array}{c}0.0024^{* *} * \\
(0.0010)\end{array}$ & $\begin{array}{c}0.0022^{* *} * \\
(0.0010)\end{array}$ & $\begin{array}{c}0.0023 * * \\
(0.0010)\end{array}$ & $\begin{array}{c}0.0024 * * \\
(0.0010)\end{array}$ \\
\hline VII*L.Union density & & $\begin{array}{c}0.0012 \\
(0.0013)\end{array}$ & $\begin{array}{c}0.0012 \\
(0.0011)\end{array}$ & $\begin{array}{c}0.0025 * * \\
(0.0010)\end{array}$ & $\begin{array}{c}0.0029 * * * \\
(0.0010)\end{array}$ & $\begin{array}{c}0.0028 * * * \\
(0.0010)\end{array}$ & $\begin{array}{c}0.0030 * * * \\
(0.0009)\end{array}$ \\
\hline$\Delta$ Union density & & $\begin{array}{l}0.0021 * \\
(0.0012)\end{array}$ & $\begin{array}{l}0.0018^{*} \\
(0.0011)\end{array}$ & $\begin{array}{c}0.0016 \\
(0.0010)\end{array}$ & $\begin{array}{c}0.0007 \\
(0.0010)\end{array}$ & $\begin{array}{c}0.0007 \\
(0.0010)\end{array}$ & $\begin{array}{c}0.0007 \\
(0.0010)\end{array}$ \\
\hline $\mathrm{III} * \Delta$ Union density & & $\begin{array}{c}0.0009 \\
(0.0013)\end{array}$ & $\begin{array}{c}0.0018 \\
(0.0015)\end{array}$ & $\begin{array}{c}0.0021 \\
(0.0015)\end{array}$ & $\begin{array}{l}0.0027^{*} \\
(0.0014)\end{array}$ & $\begin{array}{l}0.0028^{*} \\
(0.0015)\end{array}$ & $\begin{array}{c}0.0030 * * \\
(0.0015)\end{array}$ \\
\hline $\mathrm{V}-\mathrm{VI}^{*} \Delta$ Union density & & $\begin{array}{c}0.0025 \\
(0.0017)\end{array}$ & $\begin{array}{l}0.0029 * \\
(0.0016)\end{array}$ & $\begin{array}{l}0.0031^{*} \\
(0.0016)\end{array}$ & $\begin{array}{l}0.0030^{*} \\
(0.0016)\end{array}$ & $\begin{array}{l}0.0031^{*} \\
(0.0016)\end{array}$ & $\begin{array}{l}0.0031 * \\
(0.0016)\end{array}$ \\
\hline VII* $\Delta$ Union density & & $\begin{array}{c}0.0029 \\
(0.0019)\end{array}$ & $\begin{array}{l}0.0032 * \\
(0.0017)\end{array}$ & $\begin{array}{c}0.0037 * * \\
(0.0017)\end{array}$ & $\begin{array}{c}0.0040 * * \\
(0.0015)\end{array}$ & $\begin{array}{c}0.0040 * * \\
(0.0015)\end{array}$ & $\begin{array}{c}0.0042 * * * \\
(0.0015)\end{array}$ \\
\hline L.Share of high-edu & & & $\begin{array}{c}0.0030 * * * \\
(0.0005)\end{array}$ & $\begin{array}{c}0.0028^{* * *} \\
(0.0005)\end{array}$ & $\begin{array}{c}0.0027 * * * \\
(0.0005)\end{array}$ & $\begin{array}{c}0.0026 * * * \\
(0.0005)\end{array}$ & $\begin{array}{c}0.0026 * * * \\
(0.0005)\end{array}$ \\
\hline III*L.Share of high-edu & & & $\begin{array}{c}0.0021^{* *} \\
(0.0009)\end{array}$ & $\begin{array}{c}0.0015 \\
(0.0010)\end{array}$ & $\begin{array}{l}0.0017 * \\
(0.0010)\end{array}$ & $\begin{array}{c}0.0017 \\
(0.0010)\end{array}$ & $\begin{array}{l}0.0018^{*} \\
(0.0011)\end{array}$ \\
\hline V-VI*L.Share of high-edu & & & $\begin{array}{c}-0.0004 \\
(0.0006)\end{array}$ & $\begin{array}{c}-0.0001 \\
(0.0005)\end{array}$ & $\begin{array}{c}-0.0000 \\
(0.0006)\end{array}$ & $\begin{array}{c}0.0000 \\
(0.0006)\end{array}$ & $\begin{array}{c}0.0001 \\
(0.0006)\end{array}$ \\
\hline VII*L.Share of high-edu & & & $\begin{array}{c}0.0004 \\
(0.0011)\end{array}$ & $\begin{array}{c}0.0001 \\
(0.0011)\end{array}$ & $\begin{array}{c}0.0002 \\
(0.0010)\end{array}$ & $\begin{array}{c}-0.0000 \\
(0.0010)\end{array}$ & $\begin{array}{c}0.0003 \\
(0.0010)\end{array}$ \\
\hline$\Delta$ Share of high-edu & & & $\begin{array}{c}0.0036 * * * \\
(0.0004)\end{array}$ & $\begin{array}{c}0.0034 * * * \\
(0.0004)\end{array}$ & $\begin{array}{c}0.0035^{* * *} * \\
(0.0004)\end{array}$ & $\begin{array}{c}0.0035 * * * \\
(0.0004)\end{array}$ & $\begin{array}{c}0.0035^{* * *} * \\
(0.0004)\end{array}$ \\
\hline III* $\Delta$ Share of high-edu & & & $\begin{array}{c}0.0013 * * * \\
(0.0004)\end{array}$ & $\begin{array}{c}0.0012 * * * \\
(0.0004)\end{array}$ & $\begin{array}{c}0.0010^{* *} * \\
(0.0004)\end{array}$ & $\begin{array}{c}0.0009 * * \\
(0.0004)\end{array}$ & $\begin{array}{c}0.0010^{* *} * \\
(0.0004)\end{array}$ \\
\hline $\mathrm{V}-\mathrm{VI}^{*} \Delta$ Share of high-edu & & & $\begin{array}{l}-0.0010 \\
(0.0007)\end{array}$ & $\begin{array}{l}-0.0004 \\
(0.0007)\end{array}$ & $\begin{array}{c}-0.0004 \\
(0.0007)\end{array}$ & $\begin{array}{c}-0.0005 \\
(0.0007)\end{array}$ & $\begin{array}{c}-0.0004 \\
(0.0007)\end{array}$ \\
\hline VII $* \Delta$ Share of high-edu & & & $\begin{array}{c}0.0008 \\
(0.0012)\end{array}$ & $\begin{array}{c}0.0008 \\
(0.0010)\end{array}$ & $\begin{array}{c}0.0007 \\
(0.0011)\end{array}$ & $\begin{array}{c}0.0006 \\
(0.0010)\end{array}$ & $\begin{array}{c}0.0008 \\
(0.0010)\end{array}$ \\
\hline L.Share of female & & & & $\begin{array}{c}-0.0017 \text { *** } \\
(0.0005)\end{array}$ & $\begin{array}{c}-0.0014 * * \\
(0.0006)\end{array}$ & $\begin{array}{c}-0.0015^{* *} \\
(0.0006)\end{array}$ & $\begin{array}{c}-0.0013 * * \\
(0.0006)\end{array}$ \\
\hline III*L.Share of female & & & & $\begin{array}{c}-0.0004 \\
(0.0008)\end{array}$ & $\begin{array}{c}-0.0006 \\
(0.0007)\end{array}$ & $\begin{array}{c}-0.0006 \\
(0.0007)\end{array}$ & $\begin{array}{l}-0.0009 \\
(0.0008)\end{array}$ \\
\hline V-VI*L.Share of female & & & & $\begin{array}{c}0.0012 \\
(0.0009)\end{array}$ & $\begin{array}{c}0.0013 \\
(0.0009)\end{array}$ & $\begin{array}{c}0.0012 \\
(0.0008)\end{array}$ & $\begin{array}{c}0.0011 \\
(0.0009)\end{array}$ \\
\hline VII*L.Share of female & & & & $\begin{array}{c}-0.0016 \\
(0.0012)\end{array}$ & $\begin{array}{l}-0.0018 \\
(0.0012)\end{array}$ & $\begin{array}{l}-0.0017 \\
(0.0011)\end{array}$ & $\begin{array}{l}-0.0017 \\
(0.0011)\end{array}$ \\
\hline$\Delta$ Share of female & & & & $\begin{array}{c}-0.0025^{* * *} * \\
(0.0006)\end{array}$ & $\begin{array}{c}-0.0021 * * * * \\
(0.0005)\end{array}$ & $\begin{array}{c}-0.0021 * * * \\
(0.0005)\end{array}$ & $\begin{array}{c}-0.0020 * * * \\
(0.0005)\end{array}$ \\
\hline III $^{*} \Delta$ Share of female & & & & $\begin{array}{l}-0.0000 \\
(0.0008)\end{array}$ & $\begin{array}{l}-0.0005 \\
(0.0007)\end{array}$ & $\begin{array}{l}-0.0007 \\
(0.0007)\end{array}$ & $\begin{array}{l}-0.0008 \\
(0.0007)\end{array}$ \\
\hline $\mathrm{V}-\mathrm{VI}^{*} \Delta$ Share of female & & & & $\begin{array}{c}0.0012 \\
(0.0008)\end{array}$ & $\begin{array}{c}0.0011 \\
(0.0008)\end{array}$ & $\begin{array}{c}0.0011 \\
(0.0007)\end{array}$ & $\begin{array}{c}0.0010 \\
(0.0008)\end{array}$ \\
\hline VII* $\Delta$ Share of female & & & & $\begin{array}{c}-0.0003 \\
(0.0009)\end{array}$ & $\begin{array}{c}-0.0008 \\
(0.0008)\end{array}$ & $\begin{array}{c}-0.0007 \\
(0.0008)\end{array}$ & $\begin{array}{l}-0.0007 \\
(0.0008)\end{array}$ \\
\hline L.Average age & & & & & $\begin{array}{c}0.0061^{* * * *} \\
(0.0015)\end{array}$ & $\begin{array}{c}0.0061 \text { *** } \\
(0.0015)\end{array}$ & $\begin{array}{c}0.0060 * * * \\
(0.0015)\end{array}$ \\
\hline III*L.Average age & & & & & $\begin{array}{l}-0.0005 \\
(0.0032)\end{array}$ & $\begin{array}{l}-0.0003 \\
(0.0035)\end{array}$ & $\begin{array}{l}-0.0003 \\
(0.0035)\end{array}$ \\
\hline V-VI*L.Average age & & & & & $\begin{array}{c}0.0002 \\
(0.0036)\end{array}$ & $\begin{array}{c}-0.0002 \\
(0.0038)\end{array}$ & $\begin{array}{l}-0.0001 \\
(0.0037)\end{array}$ \\
\hline VII*L.Average age & & & & & $\begin{array}{c}-0.0086^{* * * *} \\
(0.0022)\end{array}$ & $\begin{array}{c}-0.0087 * * * \\
(0.0023)\end{array}$ & $\begin{array}{c}-0.0087 \text { *** } \\
(0.0022)\end{array}$ \\
\hline$\Delta$ Average age & & & & & $\begin{array}{c}0.0112 * * * \\
(0.0017)\end{array}$ & $\begin{array}{c}0.0111 * * * \\
(0.0017)\end{array}$ & $\begin{array}{c}0.0111 * * * \\
(0.0017)\end{array}$ \\
\hline III* $\Delta$ Average age & & & & & $\begin{array}{l}-0.0046 \\
(0.0031)\end{array}$ & $\begin{array}{l}-0.0051 \\
(0.0033)\end{array}$ & $\begin{array}{l}-0.0052 \\
(0.0032)\end{array}$ \\
\hline $\mathrm{V}-\mathrm{VI} * \Delta$ Average age & & & & & $\begin{array}{l}-0.0009 \\
(0.0023)\end{array}$ & $\begin{array}{l}-0.0011 \\
(0.0023)\end{array}$ & $\begin{array}{l}-0.0011 \\
(0.0023)\end{array}$ \\
\hline VII $* \Delta$ Average age & & & & & $\begin{array}{c}-0.0076 * * * * \\
(0.0027)\end{array}$ & $\begin{array}{c}-0.0077 * * * \\
(0.0026)\end{array}$ & $\begin{array}{c}-0.0077 \text { *** } \\
(0.0027)\end{array}$ \\
\hline L.Share of white & & & & & & 0.0001 & 0.0002 \\
\hline
\end{tabular}


III*L.Share of white

V-VI*L.Share of white

VII*L.Share of white

$\Delta$ Share of white

$\mathrm{III}^{*} \Delta$ Share of white

$\mathrm{V}-\mathrm{VI} * \Delta$ Share of white

VII* $\Delta$ Share of white

L.Log of real value-added

III*L.Log of real value-added

V-VI*L.Log of real value-added

VII*L.Log of real value-added

$\Delta$ Log of real value-added

III* $\Delta \log$ of real value-added

$\mathrm{V}-\mathrm{VI}^{*} \Delta \mathrm{Log}$ of real value-added

$\mathrm{VII} * \Delta \log$ of real value-added

L.Mean log earnings

III*L.Mean log earnings

V-VI*L.Mean log earnings

VII*L.Mean log earnings

Year-class FE

Observations

R-squared

Number of id

Cluster Robust standard errors at the industry level in parentheses

$* * * \mathrm{p}<0.01, * * \mathrm{p}<0.05, * \mathrm{p}<0.1$

\begin{tabular}{|c|c|}
\hline (0.0005) & $(0.0006)$ \\
\hline-0.0004 & -0.0006 \\
\hline (0.0008) & $(0.0008)$ \\
\hline 0.0005 & 0.0004 \\
\hline (0.0008) & $(0.0008)$ \\
\hline 0.0004 & 0.0003 \\
\hline$(0.0007)$ & $(0.0008)$ \\
\hline 0.0004 & 0.0004 \\
\hline$(0.0004)$ & $(0.0004)$ \\
\hline 0.0003 & 0.0003 \\
\hline$(0.0007)$ & $(0.0006)$ \\
\hline $0.0008^{*}$ & 0.0008 \\
\hline$(0.0005)$ & $(0.0005)$ \\
\hline $0.0013^{*}$ & 0.0012 \\
\hline$(0.0008)$ & (0.0008) \\
\hline & 0.0084 \\
\hline & (0.0087) \\
\hline & $-0.0240^{*}$ \\
\hline & $(0.0125)$ \\
\hline & -0.0095 \\
\hline & (0.0079) \\
\hline & -0.0189 \\
\hline & (0.0118) \\
\hline & 0.0051 \\
\hline & $(0.0233)$ \\
\hline & $-0.0450 * *$ \\
\hline & $(0.0195)$ \\
\hline & 0.0009 \\
\hline & $(0.0251)$ \\
\hline & -0.0406 \\
\hline & $(0.0362)$ \\
\hline$-0.6651 * * *$ & $-0.6658 * * *$ \\
\hline$(0.0405)$ & $(0.0405)$ \\
\hline-0.1407 & -0.1452 \\
\hline (0.0877) & $(0.0871)$ \\
\hline-0.0247 & -0.0241 \\
\hline$(0.0706)$ & $(0.0699)$ \\
\hline 0.0995 & 0.0976 \\
\hline$(0.0911)$ & $(0.0877)$ \\
\hline Yes & Yes \\
\hline 5,600 & 5,600 \\
\hline 0.4901 & 0.4919 \\
\hline 160 & 160 \\
\hline
\end{tabular}

\begin{tabular}{ccccccc}
$-0.6174 * * *$ & $-0.6370^{* * *}$ & $-0.6760 * * *$ & $-0.6892 * * *$ & $-0.6676^{* * *}$ & $-0.6651 * * *$ & $-0.6658 * * *$ \\
$(0.0485)$ & $(0.0473)$ & $(0.0455)$ & $(0.0430)$ & $(0.0402)$ & $(0.0405)$ & $(0.0405)$ \\
$-0.1399 *$ & $-0.1276 *$ & -0.1420 & -0.1164 & -0.1426 & -0.1407 & -0.1452 \\
$(0.0722)$ & $(0.0723)$ & $(0.0870)$ & $(0.0829)$ & $(0.0856)$ & $(0.0877)$ & $(0.0871)$ \\
0.0202 & -0.0336 & -0.0297 & -0.0165 & -0.0208 & -0.0247 & -0.0241 \\
$(0.0644)$ & $(0.0662)$ & $(0.0616)$ & $(0.0601)$ & $(0.0668)$ & $(0.0706)$ & $(0.0699)$ \\
0.1516 & 0.1258 & 0.1460 & 0.1089 & 0.0920 & 0.0995 & 0.0976 \\
$(0.0948)$ & $(0.1003)$ & $(0.0993)$ & $(0.0960)$ & $(0.0895)$ & $(0.0911)$ & $(0.0877)$ \\
Yes & Yes & Yes & Yes & Yes & Yes & Yes \\
5,600 & 5,600 & 5,600 & 5,600 & 5,600 & 5,600 & 5,600 \\
0.3527 & 0.3717 & 0.4324 & 0.4599 & 0.4830 & 0.4901 & 0.4919 \\
160 & 160 & 160 & 160 & 160 & 160 & 160 \\
\hline
\end{tabular}


Table A6 Results for two-way fixed-effects models for EGP classes including an interaction term between union density and computer investments, the dependent variable is the mean of In weekly earnings

\begin{tabular}{|c|c|c|c|c|c|c|c|c|}
\hline \multirow[b]{2}{*}{ VARIABLES } & \multicolumn{2}{|c|}{ I-II } & \multicolumn{2}{|l|}{ III } & \multicolumn{2}{|c|}{ V-VI } & \multicolumn{2}{|c|}{ VII } \\
\hline & coef & se & coef & se & coef & se & coef & se \\
\hline ICT investments & 0.0002 & $(0.0004)$ & 0.0010 & $(0.0006)$ & -0.0011 & $(0.0007)$ & -0.0005 & $(0.0006)$ \\
\hline Union density & $0.0019 * * *$ & $(0.0007)$ & $0.0037 * * *$ & $(0.0012)$ & $0.0039 * * *$ & $(0.0008)$ & $0.0048 * * *$ & $(0.0009)$ \\
\hline ICT investments*Union density & 0.0000 & $(0.0000)$ & -0.0001 & $(0.0000)$ & $0.0001 *$ & $(0.0000)$ & 0.0000 & $(0.0000)$ \\
\hline Share of high-edu & $0.0032 * * *$ & $(0.0004)$ & $0.0045^{* * *}$ & $(0.0004)$ & $0.0031 * * *$ & $(0.0006)$ & $0.0042 * * *$ & $(0.0010)$ \\
\hline Share of female & $-0.0019 * * *$ & $(0.0005)$ & $-0.0026 * * *$ & $(0.0003)$ & $-0.0009 * *$ & $(0.0004)$ & $-0.0030 * * *$ & $(0.0005)$ \\
\hline White non-Hispanic workers & 0.0004 & $(0.0005)$ & 0.0004 & $(0.0004)$ & $0.0009 * *$ & $(0.0003)$ & $0.0012 * *$ & $(0.0006)$ \\
\hline Average age & $0.0085 * * *$ & $(0.0017)$ & $0.0056 * *$ & $(0.0024)$ & $0.0083 * * *$ & $(0.0020)$ & 0.0020 & $(0.0014)$ \\
\hline Ln of real VA & 0.0048 & $(0.0096)$ & -0.0200 & $(0.0120)$ & -0.0030 & $(0.0130)$ & -0.0155 & $(0.0120)$ \\
\hline Mean ln Earning t-1 & $0.2866 * * *$ & $(0.0388)$ & $0.1718 * * *$ & $(0.0561)$ & $0.2779 * * *$ & $(0.0437)$ & $0.4037 * * *$ & $(0.0737)$ \\
\hline Year fixed effects & \multicolumn{2}{|c|}{ Yes } & \multicolumn{2}{|c|}{ Yes } & \multicolumn{2}{|c|}{ Yes } & \multicolumn{2}{|c|}{ Yes } \\
\hline Observations & \multicolumn{2}{|l|}{1,440} & \multicolumn{2}{|l|}{1,440} & \multicolumn{2}{|l|}{1,440} & \multicolumn{2}{|l|}{1,440} \\
\hline R-squared & \multicolumn{2}{|l|}{0.6731} & \multicolumn{2}{|l|}{0.6077} & \multicolumn{2}{|l|}{0.4547} & \multicolumn{2}{|l|}{0.5388} \\
\hline Number of id & \multicolumn{2}{|l|}{40} & \multicolumn{2}{|l|}{40} & \multicolumn{2}{|l|}{40} & \multicolumn{2}{|l|}{40} \\
\hline
\end{tabular}

Cluster Robust standard errors at the industry level in parentheses $* * * \mathrm{p}<0.01, * * \mathrm{p}<0.05, * \mathrm{p}<0.1$

Table A7 Results for fixed-effects ECMs for EGP classes including an interaction term between union density and computer investments, the dependent variable is the mean of In weekly earnings

\begin{tabular}{|c|c|c|c|c|c|c|c|c|}
\hline \multirow[b]{2}{*}{ VARIABLES } & \multicolumn{2}{|c|}{ I-II } & \multicolumn{2}{|l|}{ III } & \multicolumn{2}{|c|}{ V-VI } & \multicolumn{2}{|c|}{ VII } \\
\hline & coef & se & coef & se & coef & se & coef & se \\
\hline L. ICT investments & 0.0002 & $(0.0004)$ & 0.0007 & $(0.0006)$ & -0.0009 & $(0.0006)$ & -0.0003 & $(0.0006)$ \\
\hline L.Union density & $0.0018 * *$ & $(0.0008)$ & $0.0031 * *$ & $(0.0013)$ & $0.0039 * * *$ & $(0.0009)$ & $0.0048 * * *$ & $(0.0010)$ \\
\hline \multicolumn{9}{|l|}{ L. ICT investments* } \\
\hline L.Union density & -0.0000 & $(0.0000)$ & -0.0000 & $(0.0000)$ & 0.0001 & $(0.0000)$ & 0.0000 & $(0.0000)$ \\
\hline$\Delta \mathrm{ICT}$ investments & $0.0019 * *$ & $(0.0008)$ & $0.0024 * *$ & $(0.0011)$ & 0.0009 & $(0.0011)$ & 0.0006 & $(0.0014)$ \\
\hline$\Delta$ Union density & 0.0006 & $(0.0011)$ & $0.0036 * *$ & $(0.0013)$ & $0.0038 * * *$ & $(0.0012)$ & $0.0049 * * *$ & $(0.0010)$ \\
\hline \multicolumn{9}{|l|}{$\Delta \mathrm{ICT}$ investments* } \\
\hline$\Delta$ Union density & $0.0008 * *$ & $(0.0004)$ & 0.0005 & $(0.0015)$ & 0.0001 & $(0.0007)$ & -0.0000 & $(0.0009)$ \\
\hline L.Share of high-edu & $0.0026 * * *$ & $(0.0005)$ & $0.0045 * * *$ & $(0.0009)$ & $0.0028 * * *$ & $(0.0006)$ & $0.0029 * * *$ & $(0.0008)$ \\
\hline$\Delta$ Share of high-edu & $0.0035^{* * *} *$ & $(0.0004)$ & $0.0045^{* * *}$ & $(0.0004)$ & $0.0031 * * *$ & $(0.0006)$ & $0.0044 * * *$ & $(0.0010)$ \\
\hline L.Share of female & $-0.0013 * *$ & $(0.0006)$ & $-0.0022 * * *$ & $(0.0005)$ & -0.0003 & $(0.0006)$ & $-0.0031 * * *$ & $(0.0009)$ \\
\hline$\Delta$ Share of female & $-0.0020 * * *$ & $(0.0005)$ & $-0.0028 * * *$ & $(0.0003)$ & $-0.0010 * *$ & $(0.0005)$ & $-0.0028 * * *$ & $(0.0004)$ \\
\hline L.Average age & $0.0059 * * *$ & $(0.0015)$ & $0.0056 * *$ & $(0.0026)$ & $0.0060 *$ & $(0.0034)$ & -0.0027 & $(0.0022)$ \\
\hline$\Delta$ Average age & $0.0111 * * *$ & $(0.0017)$ & $0.0058 * *$ & $(0.0027)$ & $0.0101 * * *$ & $(0.0013)$ & $0.0034 * *$ & $(0.0016)$ \\
\hline L.Share of white & 0.0002 & $(0.0006)$ & -0.0004 & $(0.0005)$ & 0.0006 & $(0.0006)$ & 0.0005 & $(0.0005)$ \\
\hline$\Delta$ Share of white & 0.0004 & $(0.0004)$ & 0.0007 & $(0.0005)$ & $0.0012 * * *$ & $(0.0003)$ & $0.0017 * *$ & $(0.0006)$ \\
\hline L.Log of real value added & 0.0083 & $(0.0086)$ & -0.0158 & $(0.0123)$ & -0.0009 & $(0.0117)$ & -0.0104 & $(0.0118)$ \\
\hline$\Delta \log$ of real value added & 0.0049 & $(0.0234)$ & $-0.0413 *$ & $(0.0236)$ & 0.0082 & $(0.0370)$ & -0.0349 & $(0.0241)$ \\
\hline L.Mean log earnings & $-0.6653 * * *$ & $(0.0406)$ & $-0.8135 * * *$ & $(0.0841)$ & $-0.6933 * * *$ & $(0.0587)$ & $-0.5687 * * *$ & $(0.0793)$ \\
\hline Year fixed effects & \multicolumn{2}{|c|}{ Yes } & \multicolumn{2}{|c|}{ Yes } & \multicolumn{2}{|c|}{ Yes } & \multicolumn{2}{|c|}{ Yes } \\
\hline Observations & 1,400 & & 1,400 & & 1,400 & & 1,400 & \\
\hline R-squared & 0.5059 & & 0.5573 & & 0.4599 & & 0.4188 & \\
\hline Number of id & 40 & & 40 & & 40 & & 40 & \\
\hline
\end{tabular}


Figure A2. Distribution of workers in each social class by quintiles of industries ordered by the change in union density from 1984 to 2019
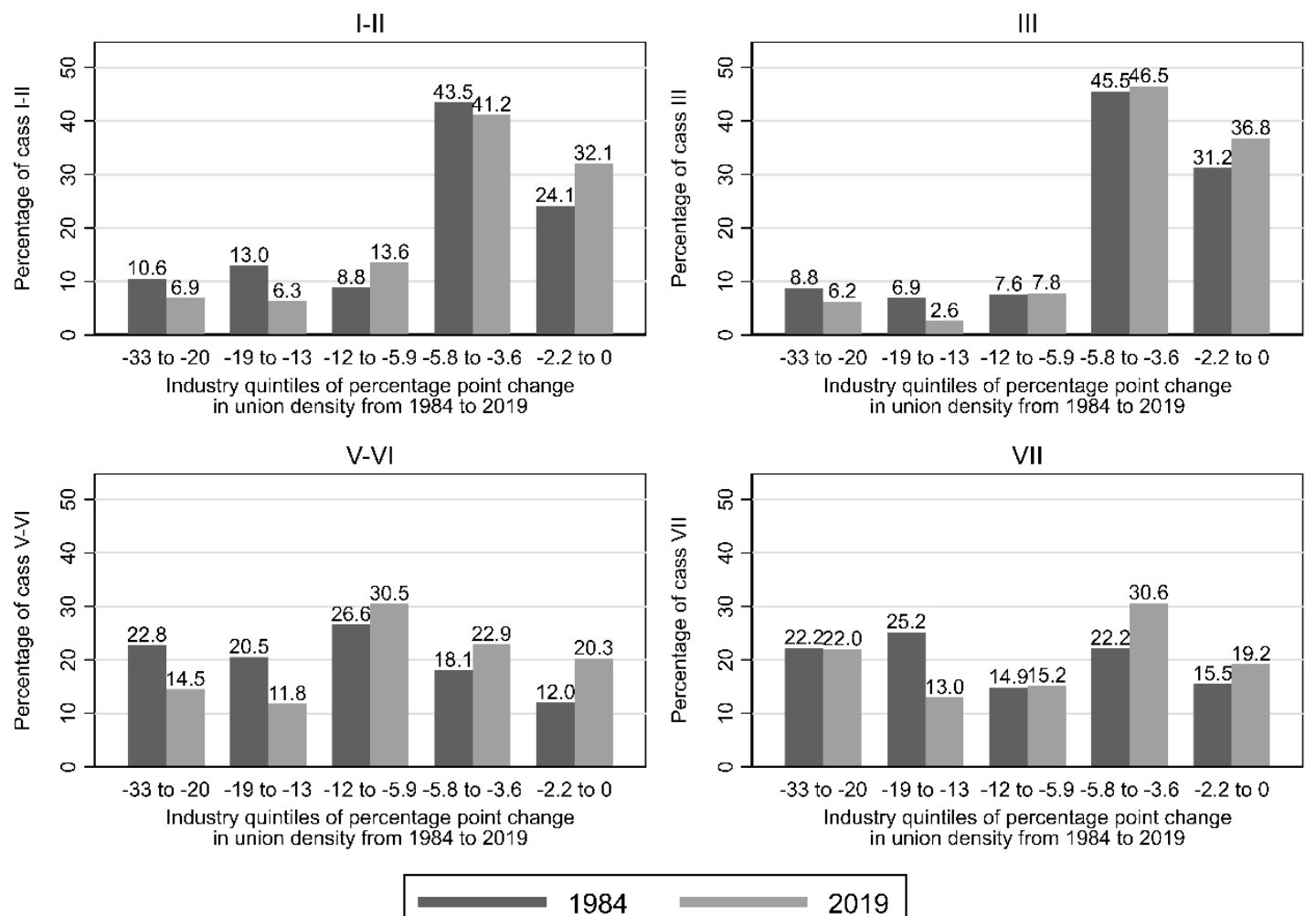

2019

Figure A3. Distribution of workers in each social class by quintiles of industries ordered by the change in ICT investments from 1984 to 2019
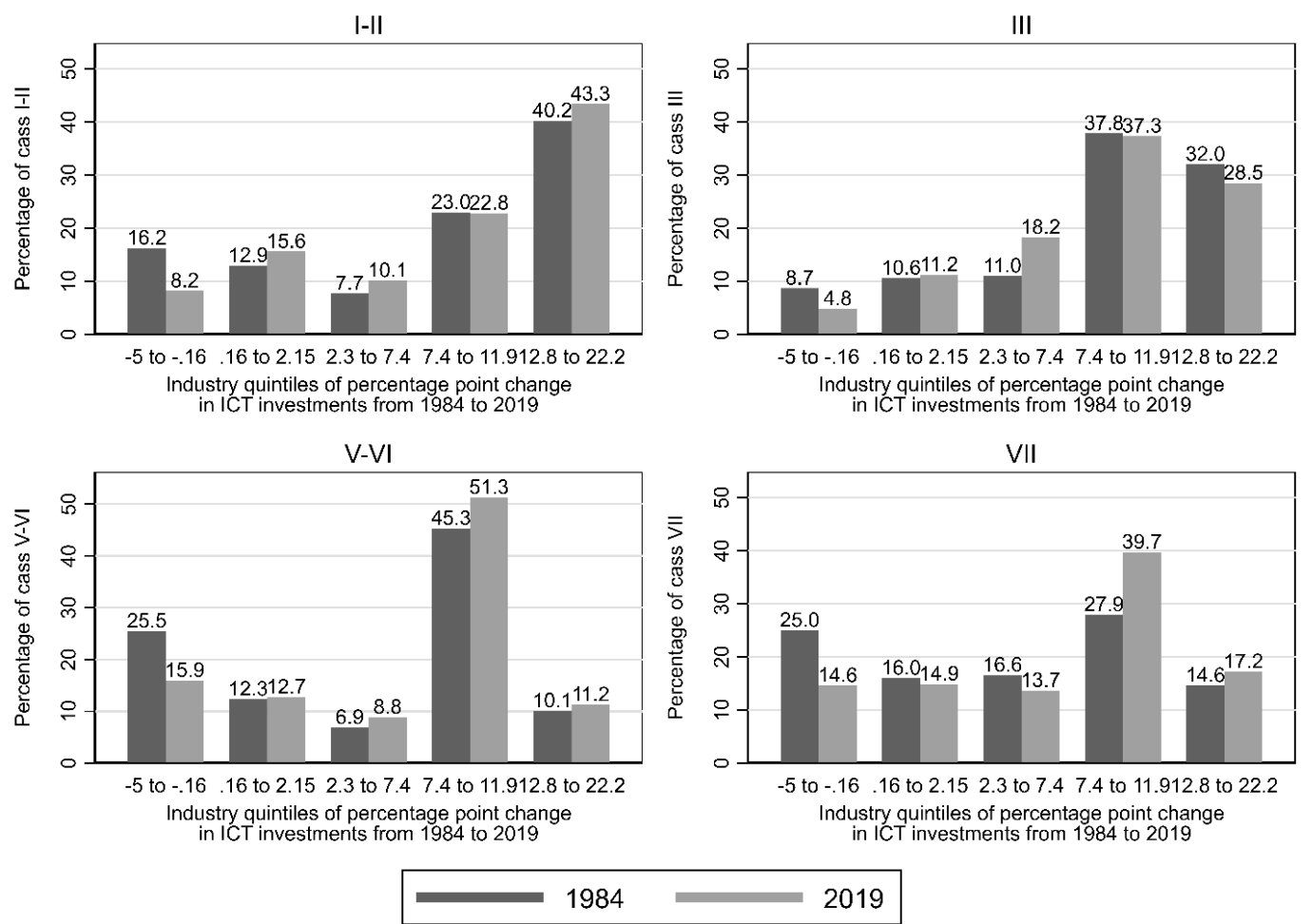


\section{Occupational and industry harmonisations}

In the period from 1984 to 2019, both industries and occupational classification underwent some revisions. Occupational codes underwent three revisions, in 1991-1992, 2002-2003, and 2010-2011. Given that EGP is constructed based on workers' occupation, these codes are first harmonised to a joint 2010 classification. The joint 2010 code was developed utilising a series of technical papers issued by the Census Bureau immediately after each census was conducted. These publications give a thorough analysis of how each census year's occupational coding scheme differs from the preceding year's system. These occupational "crosswalks" are based on case samples that have been "twice coded" into the occupational schemes of the current and preceding census years. First, the 1980 occupational code is harmonised to the 1990; this transition involves only minor transformation and mainly in the labelling of occupations. In a second step, the 1990 codes are recoded to a common 2000 occupational classification. Here occupation in the 1990 classification is translated to the 2000 occupation where the largest share of workers would have been coded according to the "double coding" provided by the census. Finally, the 2000 occupational code is translated to a common 2010, which implies only minor changes. All documents for the cross-walks are collected on the Census Bureau website (https://www.census.gov/topics/employment/industry-occupation/guidance/code-lists.html)

The crosswalks, especially from the 1990 to 2000 code, are not always straightforward, meaning that some occupations from the previous classification could be translated into more than one of the new classifications, or single occupational codes from the previous classification are split in more than one code. However, these are not significant problems for the present study since it uses broad social classes, and in almost all cases, the ambiguous recoding options fall within the same aggregate social class.

Nevertheless, some corrections are applied to the original crosswalks to maximise consistency in the observed time series. These choices are not exclusively informed by the BLS crosswalks but also by observing brakes in the class employment distribution in the CPS. However, models tested without these adjustments or with only partial adjustments return substantively identical results.

First, some occupations after 2002 are placed in class I-II despite indications from Morgan (2007); this is because they made up considerable parts of occupations 22 and 21 of the 1990 classification, which are placed in class I-II. According to the BLS crosswalk, occupation 22 "managers and administrators not elsewhere classified" and 21 "managers service organisation, n.e.c" are translated into occupation 43 and 42 of the 2000/2010 occupational classification, which belong to class I-II. However, after 2002 occupational codes 21 and 22 are split into several other 2000 codes, which in some cases are located in different EGP classes based on Morgan (2007). These are occupations 10, 33, 22, 60, 430, which are exclusively made up of individuals who in the 1990 classification would have been coded class I-II, and occupations 471 and 462 , which could be recoded both in class I-II or in V-VI and III respectively, but their positioning outside class III results in visible jumps in time series.

Finally, occupation 17 of 1990 occupational classification and the corresponding 310 and 340 of the 2000 classification are located in class I-II instead of class IIIa. This is because occupation 17 is part of occupation 19 of the 1980 classification. After 1990 occupation 19 is divided into 17, 21, and 22, most of which belongs to class I-II. Given that before 199017 was part of 19, the two occupations are kept together in class I-II to increase consistency.

Industry classification changed in 1991-1992 2002-2003 2008-2009 2013-2014. Data in investments in computer and communication technologies are provided by the BEA at the naics 2012 level, mainly at the three digits level. The starting point is the harmonisation provided by IPUMS to a common 1990 code (IPUMS USA, 2018). The common 1990 code is then translated into NAICS based on crosswalks from the Census Bureau. In order to match data on investments from the BEA and due to ambiguities in the crosswalks, some three-digit industries are reaggregated to broader two-digit ones.

Furthermore, some adjustments are made to increase consistency in classifications. Industry code 212 prior to 2003 is kept with Naics 326 as indicated by the US Census Bureau. Following IPUMS crosswalk 212 would have been placed in a residual "not specified" category, resulting in a substantial break in the time series. Industry 237, which is the direct translation of 212 after 2002, is also kept in Naics 326 following indications from Census. 
Employment in Naics 512 motion pictures and sound suddenly drops after 2002; this is because its main 1990 component 800 is broken down into two 2000 components, 657 and 856.856 is made up of previous parts of both 800 and 810 (NAICS 713). Since it is impossible to distinguish them, they are combined in a single 71 Naics.

Finally, industry 288 after 2003 is placed in Naics 333 instead of 332. After 2000 the new code 288 can be reconnected to both 331, part of Naics 333, and 290, part of Naics 332. However, after 2000, code 290 showed a sudden increase in employment and code 331 a sudden drop. For this reason, 288 is kept together with 331 of the 1990 code into Naics 333. Finally, code 392 of 1990 classification, which is a small industry of residual "not specified manufacturing" in the CPS is excluded.

\section{Table A8. Full list of industries used in the analysis}

\begin{tabular}{|c|c|c|c|}
\hline Naics & & Naics & Title \\
\hline $211-213$ & $\begin{array}{l}\text { Oil and gas extraction, and supporting activities to } \\
\text { mining }\end{array}$ & 339 & Miscellaneous manufacturing \\
\hline 212 & Mining, except oil and gas & 420 & Wholesale trade \\
\hline 22 & Utilities & $44-45$ & Retail trade \\
\hline 23 & Construction & $48-49$ & Transportation and warehousing \\
\hline $311-312$ & Food, beverage, and tobacco products & 511 & Publishing industries (including software) \\
\hline $313-314$ & Textile mills and textile product mills & $515-517$ & Broadcasting and telecommunications \\
\hline $315-316$ & Apparel and leather and allied products & $518-519$ & Information and data processing services \\
\hline 321 & Wood products & $52-55$ & Finance and insurance \\
\hline 322 & Paper products & 53 & Real estate and rental and leasing \\
\hline 323 & Printing and related support activities & 541 & Professional, scientific, and technical services \\
\hline 324 & Petroleum and coal products & 560 & Administrative and waste management services \\
\hline 325 & Chemical products & 61 & Educational services \\
\hline 326 & Plastics and rubber products & 621 & Ambulatory health care services \\
\hline 327 & Nonmetallic mineral products & 622 & Hospitals \\
\hline 331 & Primary metals & 623 & Nursing and residential care facilities \\
\hline 332 & Fabricated metal products & 624 & Social assistance \\
\hline 333 & Machinery & $71-512$ & $\begin{array}{l}\text { Arts, entertainment, and recreation, motion } \\
\text { picture and sound recording }\end{array}$ \\
\hline $334-335$ & Electronic products & 721 & Accommodation \\
\hline 336 & $\begin{array}{l}\text { Motor vehicles, bodies and trailers, parts and other } \\
\text { transportation equipments }\end{array}$ & 722 & Food services and drinking places \\
\hline 337 & Furniture and related products & 81 & Other services, except government \\
\hline
\end{tabular}

\section{Counterfactual estimates}

Counterfactual estimates are obtained by estimating model 1 using bootstrapped standard errors and predicting values of the dependent variable holding unionisation, investments in technology and share of tertiary educated constant at the 1984 levels for each social class.

Because $\mathrm{Y}$ is path-dependent in the data generating process, the predicted value of $Y_{\text {cit }}$ are predicted sequentially, that is $Y_{c i t}$ is used to predict $\hat{Y}_{c i t+1}$ and $\hat{Y}_{c i t+1}$ is used to predict $\hat{Y}_{c i t+2}$ and so on. Second, counterfactual estimates of each industry-social class combination are reaggregated to represent the whole non-agricultural private sector using industry-class-year weights reflecting the employment size of each cell, computed as the sum of sampling weights. Estimates for the actual earnings computed this way are identical to those computed from weighted microdata as in figure 1.

Upper and lower prediction bound are computed through a simulation that repeatedly solves the models each time, accounting for the uncertainty associated with the estimated coefficient vector. Since the objective 
of the study is the differences in earnings growth between classes in the period analysed, as reported in the second panel of figure 1, the reported results in figure 4 are computed as the difference between 2019 and 1984 in the counterfactual estimates for each social class, upper and lower prediction bounds of the difference are computed as the 2019-1984 change in the estimated upper and lower bounds in levels. Estimates are thus interpretable as the change in earnings from 1984 to 2019 had the level of indicated covariate remained at the 1984 values. Cumulative changes over the whole period are reported in figure A4.

It is important to note that counterfactual estimates assume independent relations among explanatory variables. Given that variables are likely associated with one another, the counterfactual estimates should be interpreted cautiously and mainly as instruments to interpret the results from the main model. The main idea is that even similar functional effects in union density would have a different impact on the overall earnings growth of different social classes due to different exposure to the phenomena.

Figure A4 Counterfactual estimates of cumulative change in In weekly earnings by EGP classes
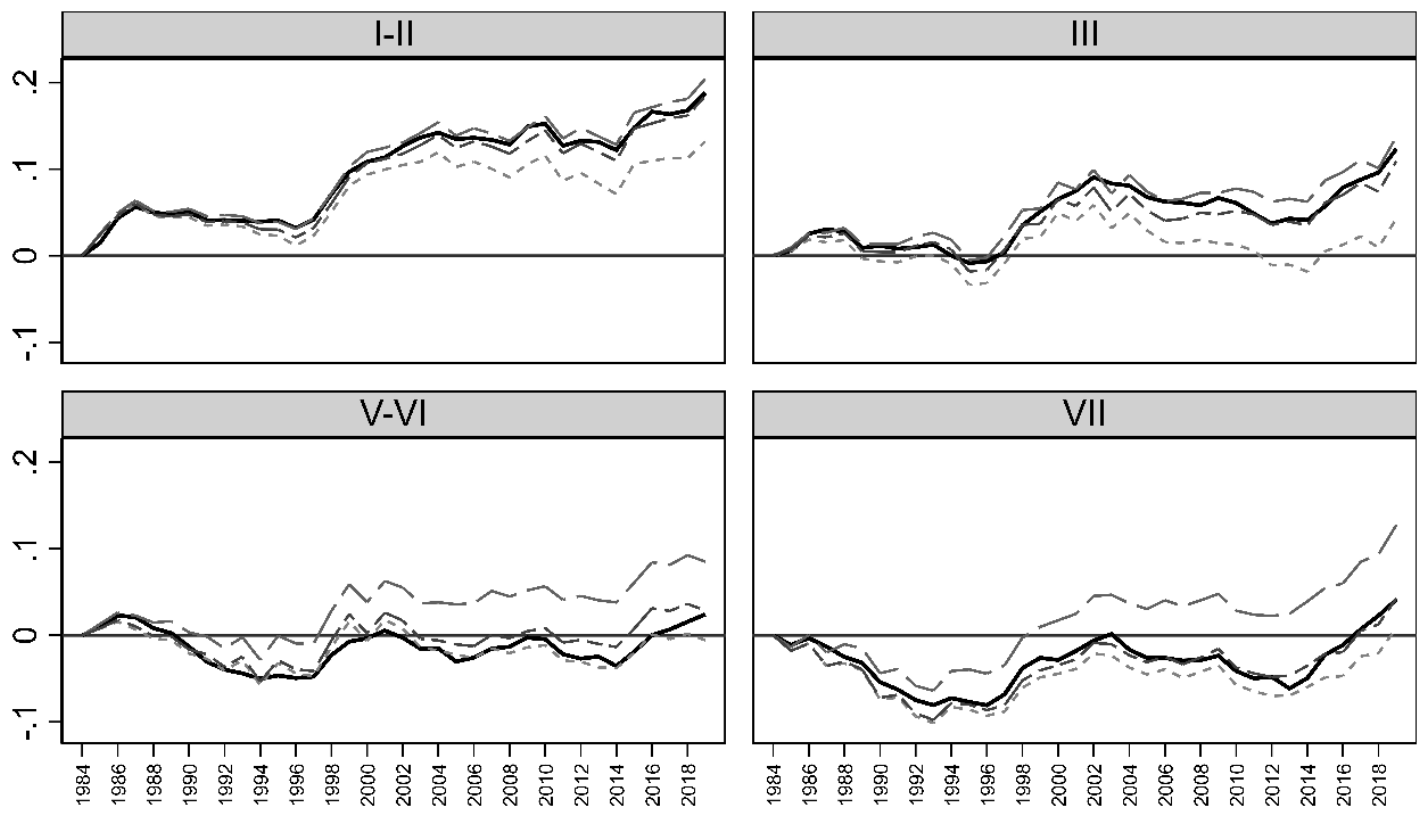

Year

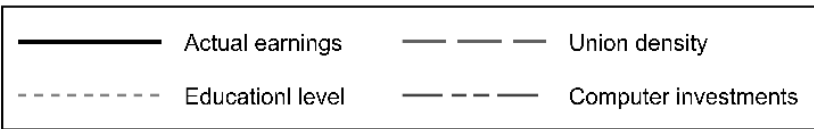

